\title{
Intra-oceanic arc growth driven by magmatic and tectonic processes recorded in the Neoproterozoic Bougmane arc complex (Anti-Atlas, Morocco)
}

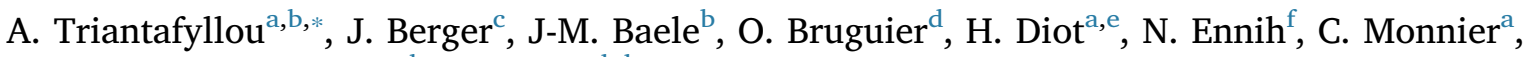 \\ G. Plissart ${ }^{\mathrm{g}}$, S. Vandycke ${ }^{\mathrm{b}}$, A. Watlet ${ }^{\mathrm{b}, \mathrm{h}}$

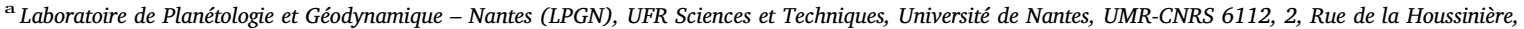 \\ BP92208, 44322 Nantes Cedex 3, France \\ ${ }^{\mathrm{b}}$ Geology and Applied Geology Unit - Mining Geology, Université de Mons, 20, Place du Parc, B-7000, Belgium \\ ${ }^{\mathrm{c}}$ Géosciences Environnement Toulouse (GET), Observatoire de Midi-Pyrénées, CNRS, IRD, Université de Paul Sabatier, UMR-CNRS 5563, 14, Avenue Edouard Belin, \\ 31400 Toulouse, France \\ d Géosciences Montpellier, Université de Montpellier 2, UMR-CNRS 5243, Place E. Bataillon, 34095 Montpellier-Cedex, France \\ e Université de La Rochelle, Avenue M. Crépeau, F-17042 La Rochelle Cedex 1, France \\ ${ }^{\mathrm{f}}$ EGGPG, Département de Géologie, Faculté des Sciences, Université Chouaib Doukkali, 24000 El Jadida, Morocco \\ ${ }^{\mathrm{g}}$ Instituo de Ciencas de la Tierra, Facultad de Ciencas, Universidad Austral de Chile (UACh), Valdivia, Chile \\ ${ }^{\text {h }}$ Royal Observatory of Belgium, Seismology-Gravimetry Section, 3, Avenue Circulaire, 1180 Bruxelles, Belgium
}

\section{A R T I C L E I N F O}

\section{Keywords:}

Arc growth

HP dehydration

Rutile dating

Garnet granulite

Neoproterozoic

Pan-African orogeny

Dehydration melting

Inttra-arc differentiation

\section{Introduction}

Intra-oceanic arc systems (IOAS) are key-geological markers of past and modern plate tectonics and are viewed as major contributors to the growth of the post-Archaean continental crust (e.g., Taylor and McLennan, 1985; Rudnick, 1995; Condie, 1997; Gazel et al., 2015). The building and growth of IOAS are marked by the thickening of its crustal section driven by successive magmatic inputs, as well as the vertical stratification of its petrological structure and geochemical composition (Tatsumi et al., 2008; Stern, 2010; DeBari and Greene, 2011). Snapshots of such mature arcs have been acquired via indirect geophysical investigations in modern environments (Izu-Bonin-Marianna or Aleutian arcs; Tatsumi et al., 2008; Calvert, 2011) and are relatively consistent with an evolutionary stage of exceptionally preserved paleo-arc sections (Talkeetna, Kohistan and Tilemsi-Amalaoulaou accreted arcs; Behn and Kelemen, 2006; Garrido et al., 2007; Burg, 2011; DeBari and Greene,
2011; Berger et al., 2011). The main consequences of arc stratification are thought to be only driven by the accumulation of several mantlederived magmatic pulses (e.g., Kelemen et al., 2003; Nikolaeva et al., 2008) and related intra-crustal differentiation processes (i.e. fractional crystallization and anatexis of infracrustal mafic rocks; e.g. Debari and Coleman, 1989; Miller and Christensen, 1994; Müntener and Hermann, 2001; Müntener and Ulmer, 2006; Garrido et al., 2006).

Thickening of the arc crust often lead to "garnetisation" of the lower crust which strongly affects the gravitational stability of the arc. There are two proposed endmember processes responsible for the growth of garnet, even on similar complexes and outcrops. (i) According to experimental data and field observations, garnet can form after crystallization at high pressure $(>1 \mathrm{GPa}$ ) from a hydrous basaltic to andesitic magma and segregation in the deep root (Müntener and Ulmer, 2006; Jagoutz et al., 2013). (ii) Garnet can also form during dehydration and dehydration-melting of amphibole-bearing lower crustal mafic rocks in

\footnotetext{
*Corresponding author at: Laboratoire de Planétologie et Géodynamique - Nantes (LPGN), UFR Sciences et Techniques, Université de Nantes, UMR-CNRS 6112, 2, Rue de la Houssinière, BP92208, 44322 Nantes Cedex 3, France.

E-mail address: antoine.triantafyllou@univ-nantes.fr (A. Triantafyllou).
} 
response to the emplacement and underplating of hornblendite, pyroxenites and gabbroic bodies (Wolf and Wyllie, 1994; Garrido et al., 2006; Berger et al., 2009, 2011).

Another possible cause of crustal thickening could be intra-oceanic tectonic activity. During subduction, the upper plate stress state depends largely on the dip of the subducting slab (Uyeda, 1983; Lallemand et al., 2005; Heuret et al., 2007; Royden and Husson, 2009). The stress regime can thus shift from extensional to compressional and vice versa in response to modifications of subduction zone dynamics (Lallemand, 2014), as also supported by analogue (Boutelier et al., 2003; Heuret et al., 2007) and numerical geodynamic modelling (Baitsch-Ghirardello et al., 2014). Although thickening of modern oceanic arcs in response to compressional upper plate stress state has not been reported yet, observations in the fossil arc records, especially for continental active margins showed that syn-subduction shortening in the upper plate can effectively lead to the thickening of the arc system (Baby et al., 1997; Haschke and Günther, 2003). Discrete phases of shortening can thus alternate with phases of magmatic accretion referred as flare-ups (e.g., DeCelles et al., 2009; Paterson and Ducea, 2015) which are well known in continental arcs but less so in their oceanic counterparts.

Petrological, structural and geophysical studies on active and Mesozoic accreted oceanic arcs reveal that growth of the arc system is mainly driven by magmatic processes rather than tectonic activity (e.g., Yoshino and Okudaira, 2004; Jicha et al., 2006; DeBari and Greene, 2011; Jicha and Jagoutz, 2015). However, direct structural and petrological observations in oceanic arc lower crust require access to exposed sections and only two Mesozoic occurrences are well characterized. Many intra-oceanic arc complexes are exposed in the Pan-African belt of West and North African continent (Dostal et al., 1994; Thomas et al., 2004; Berger et al., 2011; Triantafyllou et al., 2016), providing a unique opportunity to compare Neoproterozoic arc growth processes with Phanerozoic and active IOAS. The main purpose of this study is to investigate the crustal processes that drive the construction of IOAS during the Pan-African orogeny. This paper proposes that the Bougmane complex formed in an IOAS which reached a mature stage via a combination of intra-oceanic magmatic and tectonic processes. These results suggest that mechanisms of Neoproterozoic oceanic arc growth may slightly differ from those governing the building of Phanerozoic arcs.

\section{Geological outline and previous works}

The Bougmane complex belongs to the Central Anti-Atlas orogenic belt (South Morocco) and crops out in the southern side of the Bou Azzer inlier (Fig. 1a and b). That particular area forms a $70 \times 10 \mathrm{~km}$ window where the Neoproterozoic basement and Pan-African structures are exposed. This basement is surrounded and locally overlain by unconformable Ediacaran volcano-clastic deposits of the Ouarzazate Supergroup and late Ediacaran to Early Cambrian siliciclastic sediments (Leblanc, 1981). The Bou Azzer inlier itself consists of several stacked tectonic units interpreted as dismembered parts of a Neoproterozoic oceanic supra-subduction zone system (e.g., Saquaque et al., 1989; Bousquet et al., 2008). These units were accreted and moulded onto the northern boundary of the West African Craton (WAC), highlighted by the WNW-ESE striking Anti-Atlas Major Fault (AAMF; Fig. 1a). Based on lithology, geochronology and tectonics, the Bou Azzer inlier can be subdivided as follow:

The oldest unit forms a discontinuous band of mafic to felsic orthogneisses in the southern boundary of the tectonic window. This assemblage is exposed in several complexes (D'Lemos et al., 2006; Blein et al., 2014) that are from east to west: Bougmane, Tazigzaout, Oumlil and Bou Azzer Mine complexes (Fig. 1b). These rocks were originally interpreted as the Eburnean basement of the WAC due to their intense deformation in comparison to other Proterozoic rocks in the Zenaga inlier (Choubert, 1963; Leblanc, 1981; Saquaque et al., 1992).
However, recent geochronological data (U-Pb dating on zircons) confirmed their Neoproterozoic ages around 755-750 Ma (D'Lemos et al., 2006; Blein et al., 2014). These rocks were then intruded by mafic to felsic magmas dated from 710 to $690 \mathrm{Ma}$ (D'Lemos et al., 2006; El Hadi et al., 2010; Blein et al., 2014; this study). According to $\mathrm{Nd}$ isotopic signature $\left(\varepsilon_{\mathrm{Nd}}\right.$ from +4.9 to +6.0$)$, all the rocks from the Tazigzaout complex were formed in oceanic settings (D'Lemos et al., 2006).

An ophiolitic assemblage is exposed in the core of the inlier. It is mainly made up of ultramafic rocks (serpentinites and few chromite pods), but also mafic meta-cumulates, meta-basaltic sheeted dykes and pillow lavas in a smaller extent (Leblanc, 1975, 1981). The geochemical signature points to an emplacement in a supra-subduction zone (SSZ) setting (Bodinier et al., 1984; Naidoo et al., 1991; Ahmed et al., 2005; Hodel et al., 2017). Precise radiometric dating of an igneous event forming this oceanic crust has not been performed yet. However, by comparison with the Sirwa window and using local relative geochronology, the igneous events can be bracketed between 760 and $660 \mathrm{Ma}$ (Thomas et al., 2004; El Hadi et al., 2010; Blein et al., 2014). According to the tectonic model sketched by Bousquet et al. (2008) and El Hadi et al. (2010), significant thrust and tectonic stacking occurred between the ophiolitic remnants to the north and the old orthogneissic units to the south during Pan-African orogeny. However, the timing of this tectonic episode is still poorly constrained even if it is generally interpreted as synchronous to the obduction stage of oceanic relics onto the WAC margin (Bousquet et al., 2008).

Intrusive syn-kinematic dioritic to granodioritic plutons cut across both gneissic and ophiolitic units (Fig. 1b). Their emplacement was dated (U$\mathrm{Pb}$ on zircons) between 660 and $640 \mathrm{Ma}$ (Inglis et al., 2004; El Hadi et al., 2010; Walsh et al., 2012; Blein et al., 2014) and show arc-like geochemical fingerprints (Beraaouz et al., 2004). Beraaouz et al. (2004) suggest that some of these dioritic plutons have an adakitic affinity. Their isotopic signature ( $E N d$ : +4.2 to +8.1 ; Mrini, 1993; Beraaouz et al., 2004) argue for an intra-oceanic emplacement.

The whole subduction-related igneous pile is also intercalated with diverse deep oceanic deposits which consist in reworked sedimentary and volcano-sedimentary deposits (Leblanc, 1975; Leblanc and Billaud, 1978) and later unconformably and partially overlain by molassic deposits from the Tiddiline formation (Hefferan et al., 1992).

The Bougmane complex studied in this paper is located in the southern central part of the Bou Azzer inlier (Fig. 1b). It is made of gabbroic, granodioritic to granitic orthogneisses, described as a "leptyno-amphibolitic complex" in recent mapping survey and recently dated at $745 \pm 5 \mathrm{Ma}$ by U-Pb on protolithic zircon (Admou et al., 2013). Localized shear zones are suspected to have affected this complex under middle to low pressure-temperature (P-T) conditions (Rahimi et al., 1998). These host gneisses are associated with a metagabbroic unit dated at $697 \pm 8 \mathrm{Ma}$ (U-Pb on zircons) and interpreted as a dismembered element of the ophiolitic assemblage being tectonically extruded to the south (El Hadi et al., 2010, 2011). To the north of the complex, the gneissic units are intruded by granodioritic and tonalitic elongated plutons that have been dated at $702 \pm 5 \mathrm{Ma}$ with inheritance of older zircon crystallized at $743 \pm 9$ Ma (cf. supplementary data in Admou et al., 2013). These intrusions have attributed to the same igneous event represented by the Bougmane intrusive granodiorite by Admou et al. (2013) based on their similar mineralogical content. The geological significance of the Bougmane units remains unclear and deserves more detailed petrological studies to decipher the processes contributing to the build-up of supra-subduction oceanic systems.

\section{Field relations and samples description}

The Bougmane complex is mainly composed of two NW-SE trending units: (i) a banded gneiss unit intimately related to (ii) an undeformed to weakly deformed plutonic unit (Fig. 2). It is limited to the NE by a dextral strike-slip fault making the contact with augen granitic gneiss, and to 


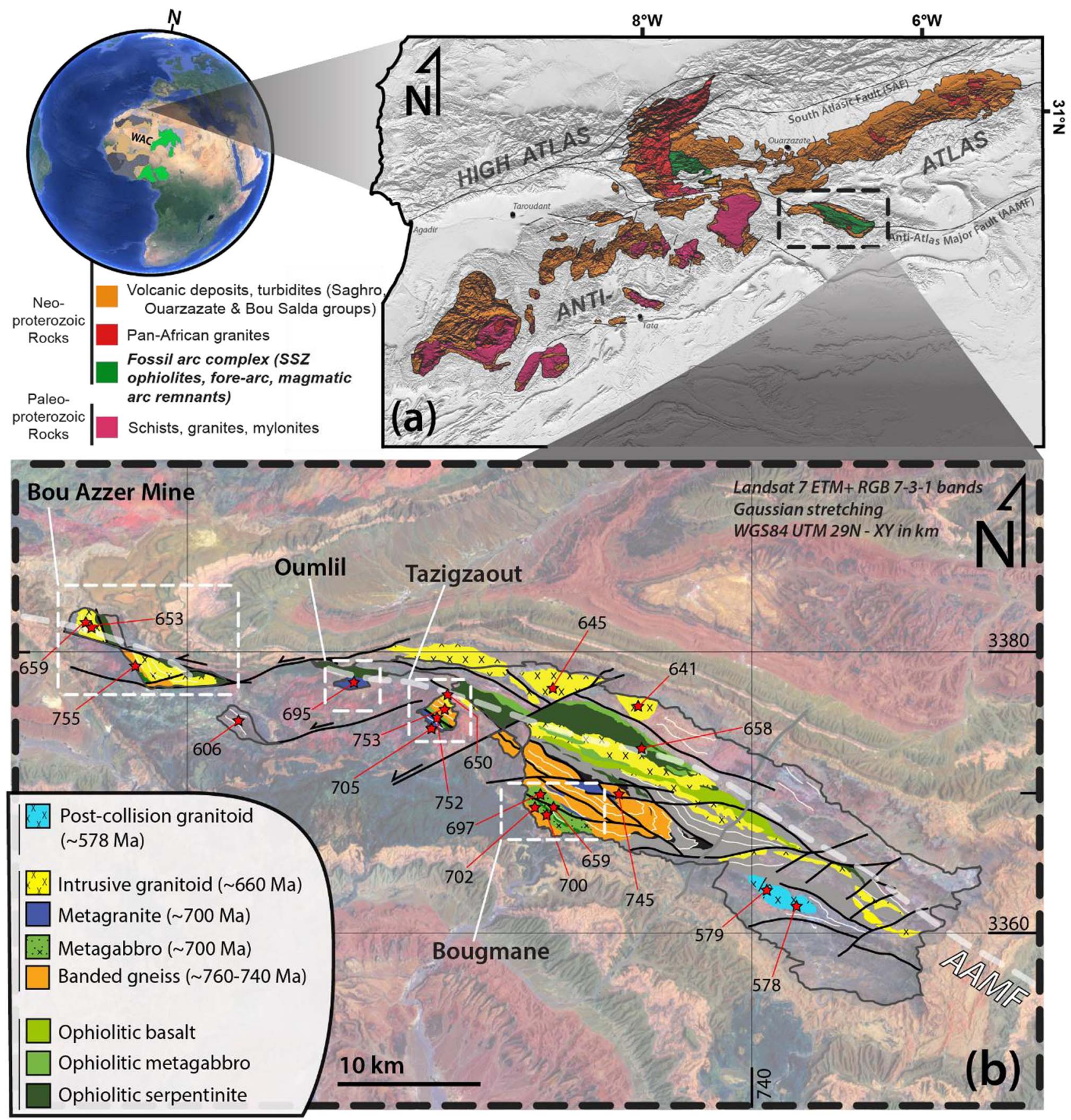

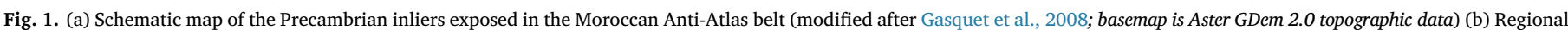

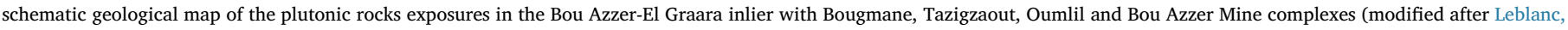

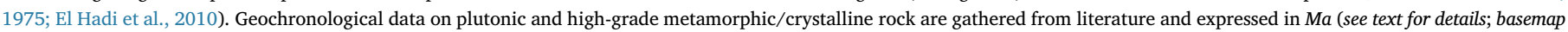
is a Landsat 7 ETM + enhanced (7-3-1 RGB) multispectral composition).

the SW by unconformable Ediacaran to Lower Cambrian deposits (Fig. 2) directly lying onto the banded gneiss.

\subsection{The banded gneiss unit}

The banded gneiss unit crops out in the southern and in the northern parts of the investigated area (Fig. 2). It consists of granodioritic orthogneiss ( $\mathrm{Pl}+\mathrm{Qz}+\mathrm{Kfs}+\mathrm{Ms}$; see Whitney and Evans, 2010 for mineral abbreviations; Fig. 3a) occasionally interlayered with amphibolites (Amp + Pl \pm Qz; Fig. 3b). Amphibolites occasionally form continuous bands but mainly occur as decimetre- to metre-scale ellipsoidal structures boudinaged within the granodioritic gneiss (Fig. 3b).
Such structures likely represent a relic of magmatic mingling between both magmas. This lithological banding is transposed by a highly dipping foliation striking mainly E-W to WNW-ESE. This one strictly cuts across the amphibolite lenses which is consistent with a solid-state deformation overprint on primary magmatic structures (Fig. 3b). The granodioritic orthogneiss also displays stromatic migmatitic structures near the contact with the intrusive unit. It is marked by the development of weakly deformed segregated leucosomes alternating at centimetre-scale with a melanosome and the gneissic paleosome (Fig. 3d). These migmatitic structures formed near the southern boundary with the intrusive unit and can be interpreted as resulting from contact metamorphism during intrusion of the hornblende-gabbros. This 


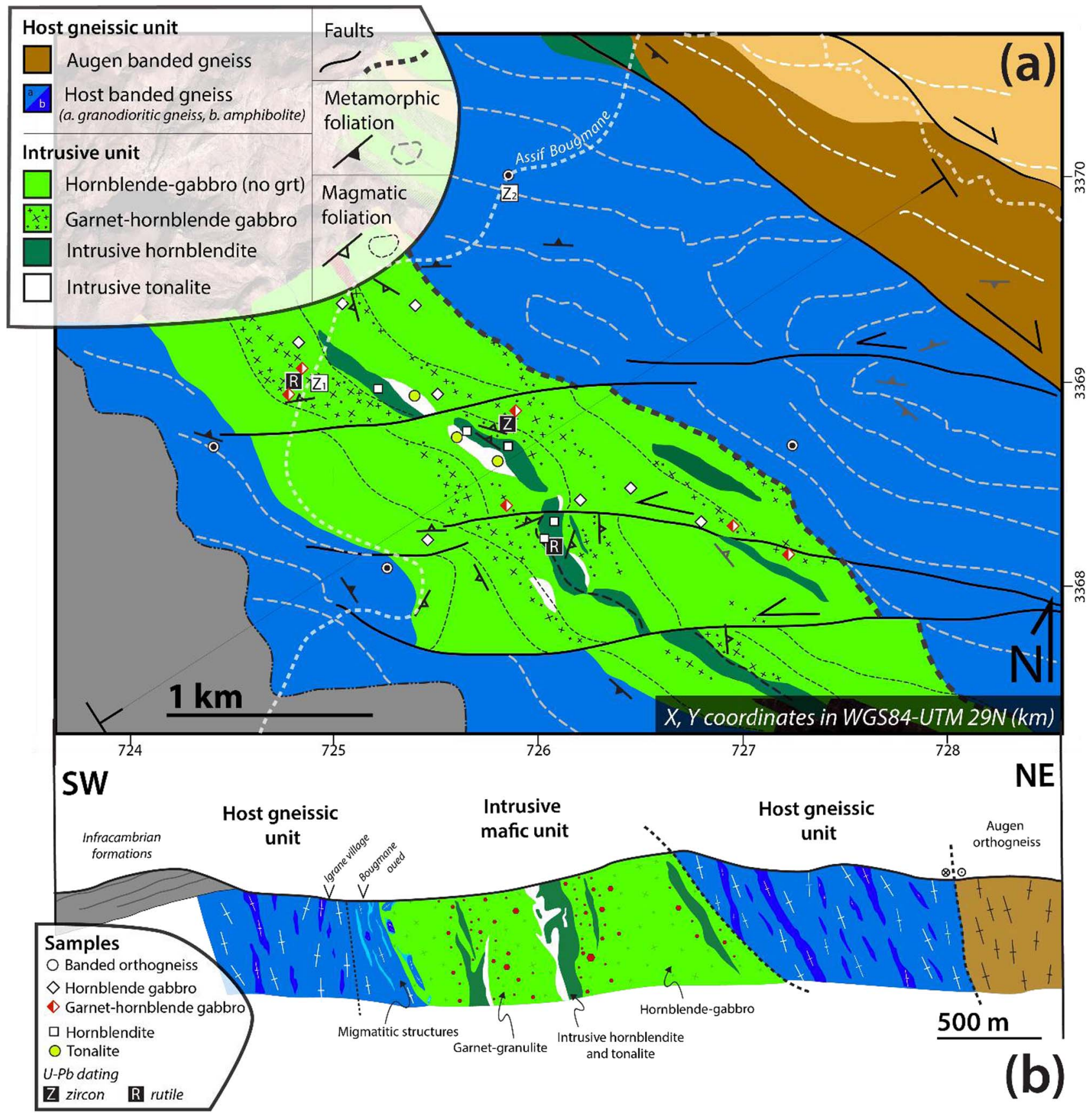

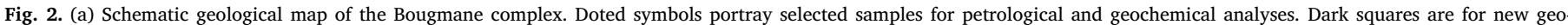

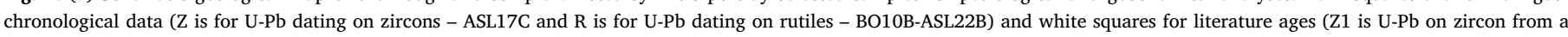

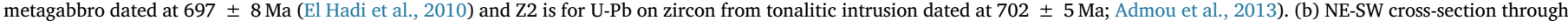
Bougmane complex. Metamorphic foliations are black (from this study) and grey (from literature; Leblanc, 1981).

intrusive relation is also supported by the observation of numerous decimetric to metric smooth rounded enclaves of banded gneisses within the intrusive units at this same contact (Fig. 3c).

\subsection{The intrusive unit}

The core of the Bougmane complex is made of several undeformed to poorly deformed plutonic bodies. They mainly consist of mafic lithologies (i.e. hornblende-gabbro and garnet-bearing gabbro), intimately associated with several metric to pluri-decametric lenses of hornblendite and tonalitic intrusions (Fig. 2).

\subsubsection{The hornblende-gabbro}

The hornblende-gabbro represents the main lithology of the intrusive unit and forms metric to decametric alternating layers of melanocratic and more leucocratic gabbroic rocks. The progressive transition between both facies at the mineralogical scale is consistent with magmatic layering rather than intrusive contacts. This banding is subparallel to the orientation of the entire unit striking NW-SE. Under the microscope, the hornblende-gabbros show a medium- to coarse-grained hypidiomorphic texture (Pl + Ca-Amp + few Qz and rutile + zircon + apatite as accessory minerals). The general fabric shows a weak shape-preferred orientation of plagioclase without any internor intra-grain deformation consistent with a magmatic fabric. Accessory rutiles are located at amphibole joints or, more rarely, as 

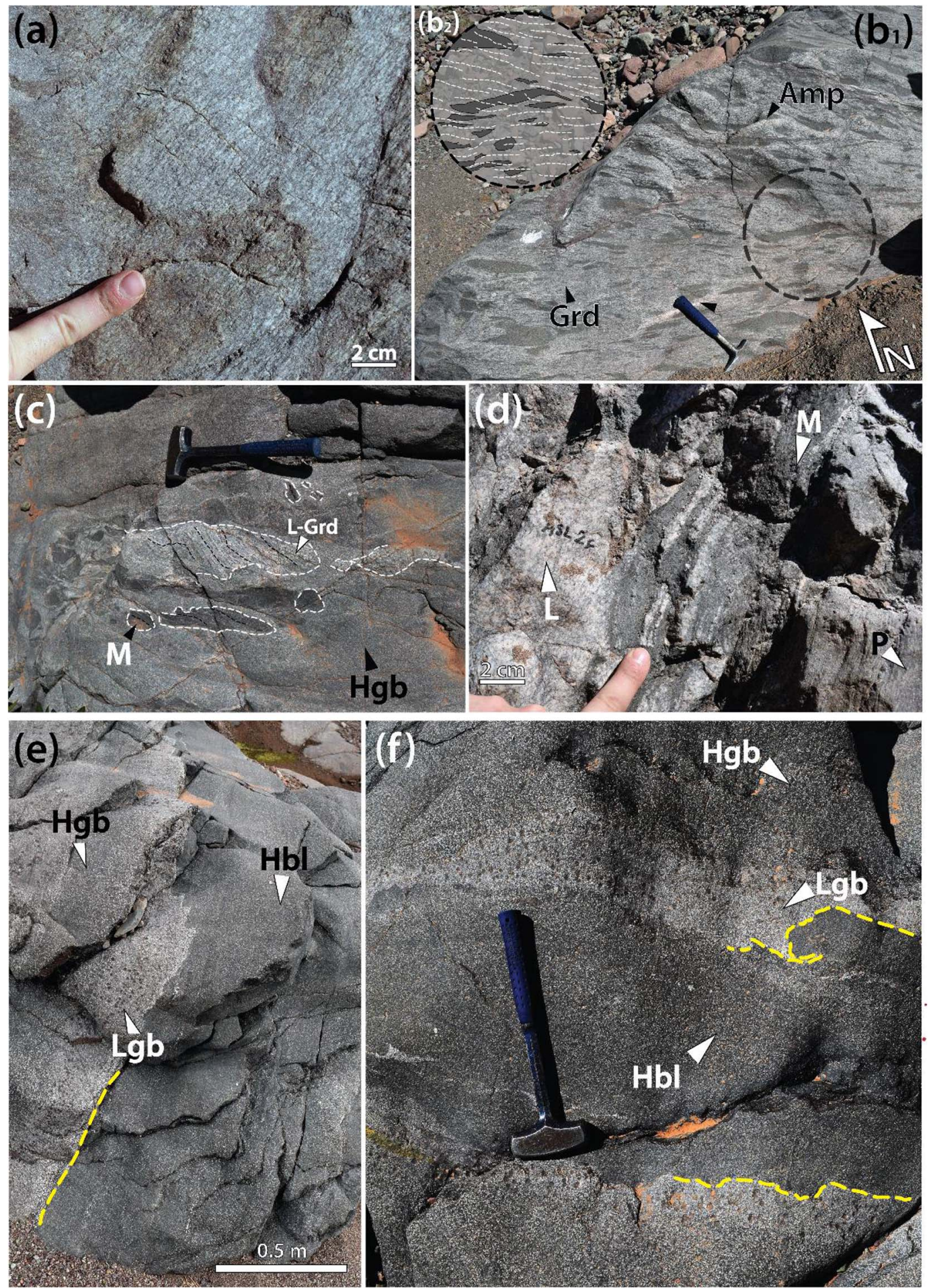

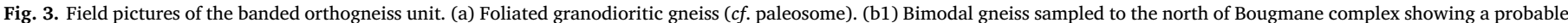

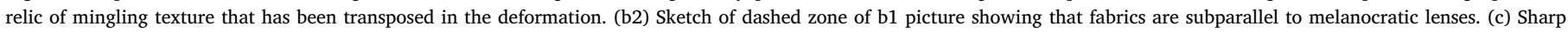

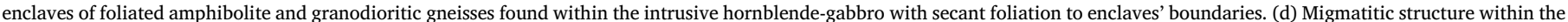

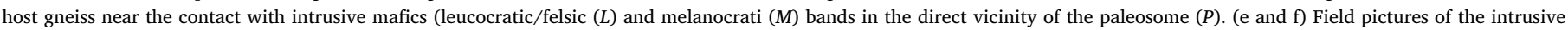

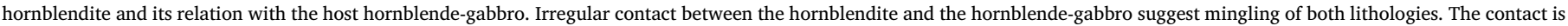

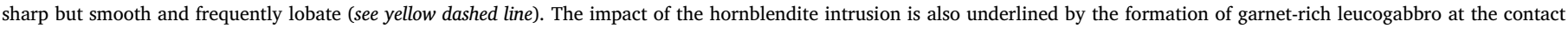

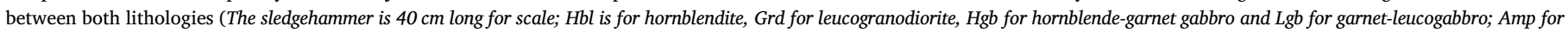
amphibolite). (For interpretation of the references to color in this figure legend, the reader is referred to the web version of this article.)

small rounded inclusions. Retrograde epidote is frequent as symplectitic texture with retrogressed plagioclase. Other secondary phases consist of sericite replacing plagioclase, of chlorite/magnetite assemblages for amphibole and of small ilmenite rims for rutile.

\subsubsection{The hornblendite}

Medium- to coarse-grained hornblendite forms several plugs into the central and northern part of the intrusive unit, intruding the previously described hornblende-gabbros (Figs. 2 and $3 e$ and $\mathrm{f}$ ). The 
igneous bodies are metric to decametric, NW-SE elongated, being locally accompanied by finer-grained intrusive melanocratic/hornblenditic rocks (Fig. 3e). The contact between the hornblendite plugs and the hornblende-gabbros is sharp but irregular and lobate resulting in cauliflower-like structures (Fig. 3e and f). Such structures attest that the hornblendites have been emplaced under high temperature near- to supra-solidus conditions. Hornblendite occasionally contains interstitial plagioclase-rich pools, probably representing a late-crystallization melt that have been trapped or locally segregated as veinlets cutting across the hornblenditic rock.

Under the microscope, the hornblendites are nearly monomineralic, made of medium- to coarse-grained (pluri-millimetric to centimetric) amphiboles. The microtexture in fresh samples typically shows euhedral shapes, sharp grain boundaries and amphibole twins suggesting that crystallization proceeded under hydrous magmatic conditions. Late crystallization of plagioclase and rare quartz is found at intergrain spaces. Rutile, rare titanite, and apatite are also frequent as accessory phases.

\subsubsection{The tonalitic intrusions}

Several metric to pluri-metric dykes of medium-grained felsic rocks also cut across the intrusive unit and are spatially related to the main hornblendite body in its central part (Fig. 2). The tonalite-hornblendite contact is irregular. Rounded enclaves of tonalite are found into the hornblenditic rocks and vice versa. These field relations can be interpreted as syn-magmatic mingling. At microscopic scale, the tonalites show a relatively fresh texture with equigranular medium-grained fabric, made of plagioclase + quartz + rare K-feldspar + muscovite/ biotite assemblages and magnetite/titanite as well as apatite as accessory minerals. Micas and titanite/magnetite assemblages form centimetre-scale patches surrounded by a lighter halo. Quartz is typically found as an interstitial phase or as plagioclase-quartz assemblages suggesting destabilization of primary plagioclase and proximal recrystallization. The contact between plagioclase and recrystallized quartz is highlighted by cuspate microstructures. These microscopic observations are consistent with significant grain-shape adjustment under HT subsolidus conditions (Gower and Simpson, 1992; Plissart et al., 2012).

\subsubsection{The garnet-bearing hornblende-gabbro and felsic veins}

Garnet-bearing rocks are very common in the core of the intrusive unit and seem spatially related to hornblendite. Based on field observations, two main types of garnet bearing facies can be distinguished:

(i) Garnet-bearing hornblende gabbros are characterized by a hypidiomorphic texture and are mainly made of pargasitic amphibole, plagioclase, garnet, rutile, epidote sensu stricto., rare quartz and apatite as accessory minerals. Garnets also occur in more leucocratic gabbroic rocks located at the margins of intrusive hornblendites. They form a garnet-rich zone with a porphyroblastic texture similar to that in the host but with a higher modal proportion of plagioclase. In both rock types, garnets are euhedral, relatively coarse compared to the gabbroic matrix and generally contain few relics of plagioclase and amphibole inclusions attesting their subsequent growth as a metamorphic phase. Rutiles are found in the hornblende-gabbroic matrix and rare rounded inclusions were observed at the rims of garnet porphyroblasts.

(ii) Garnet-bearing leucosomes. Garnets are also found associated to felsic/plagioclase-rich leucosomes either forming incipient melting structures within the host rock or veins cutting across the (garnet-) hornblende-bearing mafic rocks. Incipient melt textures (Fig. 4a) are very similar to patch-migmatites found in partially molten metapelites (Sawyer and Brown, 2008). They are characterized by coarse subhedral incongruent garnets with leucosomes assemblages (i.e. $\mathrm{Pl}+\mathrm{Qz}+$ few K-fs) forming patches in the host mafic rock. Under the microscope, the coarse garnets are subhedral to anhedral and show embayments of quartz and plagioclase at their outer rims, suggesting that garnet rims formed during partial melting (Fig. 4b). Garnet-rich felsic veins intruding the host hornblende-gabbro formed after segregation of the melt coming from incipient melting domains (Fig. 4c). The contact zone between host hornblende-gabbro and these garnet-rich felsic veins is generally depleted in plagioclase suggesting that the host rock contributed to the melt-forming reaction. The veins are made of $\mathrm{Pl}+\mathrm{Grt}+$ rare Qz. Garnets found in leucosomes veins are euhedral and have variable sizes (millimetric to pluricentimetric). Monomineralic garnetite layers are also found occasionally in the surroundings of small relic leucosomes, suggesting garnet accumulation after melt escape (Fig. 4d).

\section{Mineral chemistry and pressure-temperature records}

Electron microprobe analyses (EPMA) were performed on major phases of each lithological facies of the Bougmane intrusive unit. In situ major element contents were used to constrain P-T conditions using different empirical thermobarometers based on single phase composition (amphibole: Anderson and Smith, 1995; Ernst and Liu, 1998; and rutile: Watson et al., 2006; Tomkins et al., 2007) and multi-phases equilibrium (amphibole-plagioclase: Blundy and Holland, 1990; Holland and Blundy, 1994; garnet-amphibole-plagioclase-quartz assemblage, Kohn and Spear, 1990; Dale et al., 2000) depending on petrographical relations and freshness of analysed phases. The range and a weighted mean (i.e. weighting each measurement in proportion to its error) for P-T estimates are presented in Table B3 and further discussed. EPMA analyses and structural formula calculations stand in Tables B2 and B3 as well as details on microprobe analytical procedures in Appendix A.1.

\subsection{Hornblende-gabbro}

Three samples of garnet-free hornblende-gabbros (BO33, BO8 and BO-hbl1) were chosen for EPMA analyses. Fresh plagioclases have composition that mainly ranges within the andesine field (54 < xAb < 71 mol. $\% ; x A b=\mathrm{Na} /[\mathrm{Na}+\mathrm{Ca}+\mathrm{K}]$ on molar basis). Only rare feldspars contain up to $20 \mathrm{~mol} . \%$ of $\mathrm{X}_{\mathrm{Or}}$ for the more albitic crystals. Calcic amphiboles (Ca apfu $>1.7$ ) are homogeneous with restricted variations in Si content (6.2-6.7 apfu Si[iv]), slight enrichment in alkali elements $(0.44<\mathrm{Na}+\mathrm{K}[\mathrm{A}]<0.63)$ and $\mathrm{Mg} \#$ ranging from 53 to $67 \mathrm{~mol} \%$. They are all defined as Mg-rich pargasitic amphiboles (Al[iv] > Fe3 + apfu; Leake et al., 2004).

In these samples, temperatures have been calculated using the Ti-inamphibole thermometer of Ernst and Liu (1998). This thermometer requires an excess of $\mathrm{Ti}$ in the chemical system which is attested by the presence of Ti-rich accessory phases (i.e. rutile, ilmenite and/or titanite) in the mineralogical assemblage. The accuracy of this thermometer has been estimated at $\pm 40{ }^{\circ} \mathrm{C}$ (Debret et al., 2013 and references therein). For fresh plagioclase, the Blundy and Holland (1990) and Holland and Blundy (1994) thermometer based on amphibole-plagioclase pairs was applied and gave temperature estimates similar to those calculated with the Ti-in-amphibole method (Table B3), a weighted mean of $691 \pm 21^{\circ} \mathrm{C}$ (95\% confidence; data range: $652-740^{\circ} \mathrm{C}$; Fig. $\left.5 a\right)$. Pressure conditions of pargasite crystallization was calculated using their $\mathrm{Al}$ content and the empirical barometer of Anderson and Smith (1995) that was calibrated for a large range of pressure-temperature conditions and for which the accuracy is estimated at $\pm 0.6 \mathrm{kbar}$. Pressure estimates pointed to a weighted mean of $8.6 \mathrm{kbar}$ (data range: 6.1-11.2 kbar; Fig. 5a).

\subsection{Garnet-bearing mafic rocks}

\subsubsection{Garnet-hornblende gabbro}

Four samples (BA9, ASL17B, BO10B and BO22A) of garnet- 

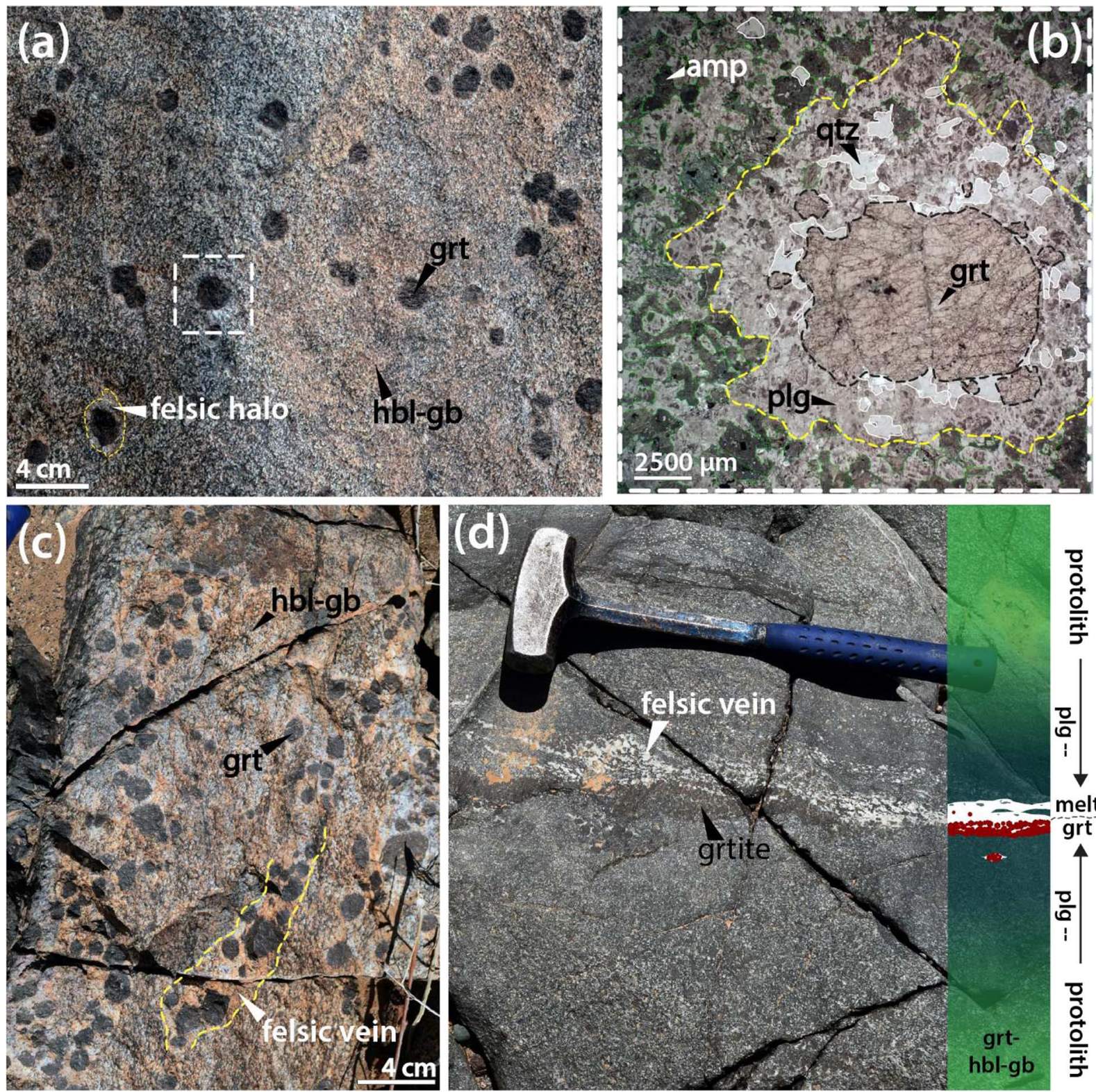

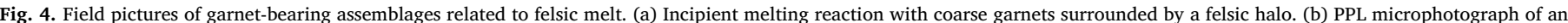

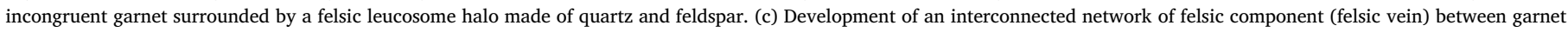

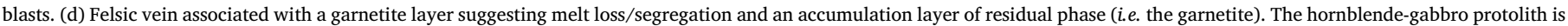
depleted in plagioclase over a distance of ca. $15 \mathrm{~cm}$ from the vein, evidencing a progressive 'sinking' of plagioclase crystals to the vein (the sledgehammer for scale is $40 \mathrm{~cm}$ long).

hornblende gabbro were analysed by EPMA. Amphiboles show typical twinned crystals and have Mg-rich pargasitic compositions similar to that in hornblende-gabbro (Ca apfu > 1.6; 6.1-6.7 apfu Si[iv]; $\mathrm{Na}+\mathrm{K}$ [A] > $0.46 \mathrm{apfu}$; $\mathrm{Mg} \#$ ranging between $48 \%$ and $66 \%$ ) except for $\mathrm{Ti}$, $\mathrm{Na}$ and $\mathrm{K}$ contents that are slightly higher in garnet-bearing rocks. Garnets are pyrope-almandine $\left(\mathrm{X}_{\mathrm{Alm}}\right.$ : 48-57; $\mathrm{X}_{\mathrm{Prp}}$ : 22-34; $\mathrm{X}_{\mathrm{Grs}}$ : $15-21$ and $\mathrm{X}_{\mathrm{Sps}}$ : 2-6; Fig. 6). Microprobe traverses across garnets from core to rim show slightly decreasing $\mathrm{X}_{\mathrm{Alm}}, \mathrm{Fe} \#$ and $\mathrm{X}_{\mathrm{Grs}}$ contents and increasing $\mathrm{X}_{\mathrm{Prp}}$ contents near the core of the garnet. Then, at their narrow rims, an intense chemical shift is observed marked by an increase in Fe\#, $\mathrm{X}_{\mathrm{Alm}}$ and $\mathrm{X}_{\mathrm{Grs}}$ contents and a decrease in $\mathrm{X}_{\operatorname{Prp}}$ and a slight $\mathrm{X}_{\mathrm{Sps}}$ contents. Plagioclases are mostly albitic in composition ranging from pure albite to $52 \% \mathrm{X}_{\mathrm{Ab}}$ for the more calcic plagioclases.

\subsection{2. $P$-T constraints for garnet-bearing mafic rocks}

Ti-in-amphibole thermometer has been used to constrain temperature of amphiboles crystallization for both garnet-bearing mafics.
Calculated temperatures show similar ranges for both rocks and point to a weighted mean value of $770{ }^{\circ} \mathrm{C}$ (data range: 693-852 ${ }^{\circ} \mathrm{C}$; Fig. 5a). Pressure conditions were estimated using Al-in-amphibole barometer and led to a weighted mean pressure conditions of $10.3 \mathrm{kbar}$ (data range: 8.3-12.7 kbar; Fig. 5a) which is in agreement with pressure estimates calculated with GAPQ barometer (ranging between 8.7 and $9.8 \mathrm{kbar}$ in sample BO24 for which grt-Pl-amp-q are in equilibrium; Dale et al., 2000).

Similar to hornblende-gabbro samples, rutiles are found either in the gabbroic matrix or as rare inclusions into the rims of garnets porphyroblasts suggesting that they crystallized after the growth of garnet cores. Fourteen rutiles from garnet-hornblende gabbro sample (BO10B sample also used for rutile U-Pb dating) were analysed in situ by LA-SFICP-MS for their trace elements content (see Table B6 for the analytical procedure and calibration). Mean content for $\mathrm{Zr}$ is $956 \mathrm{ppm}$ (standard deviation of 89). The large standard deviation reflects $\mathrm{Zr}$ heterogeneities/zoning at the crystal scale that was sampled as a bulk with the 


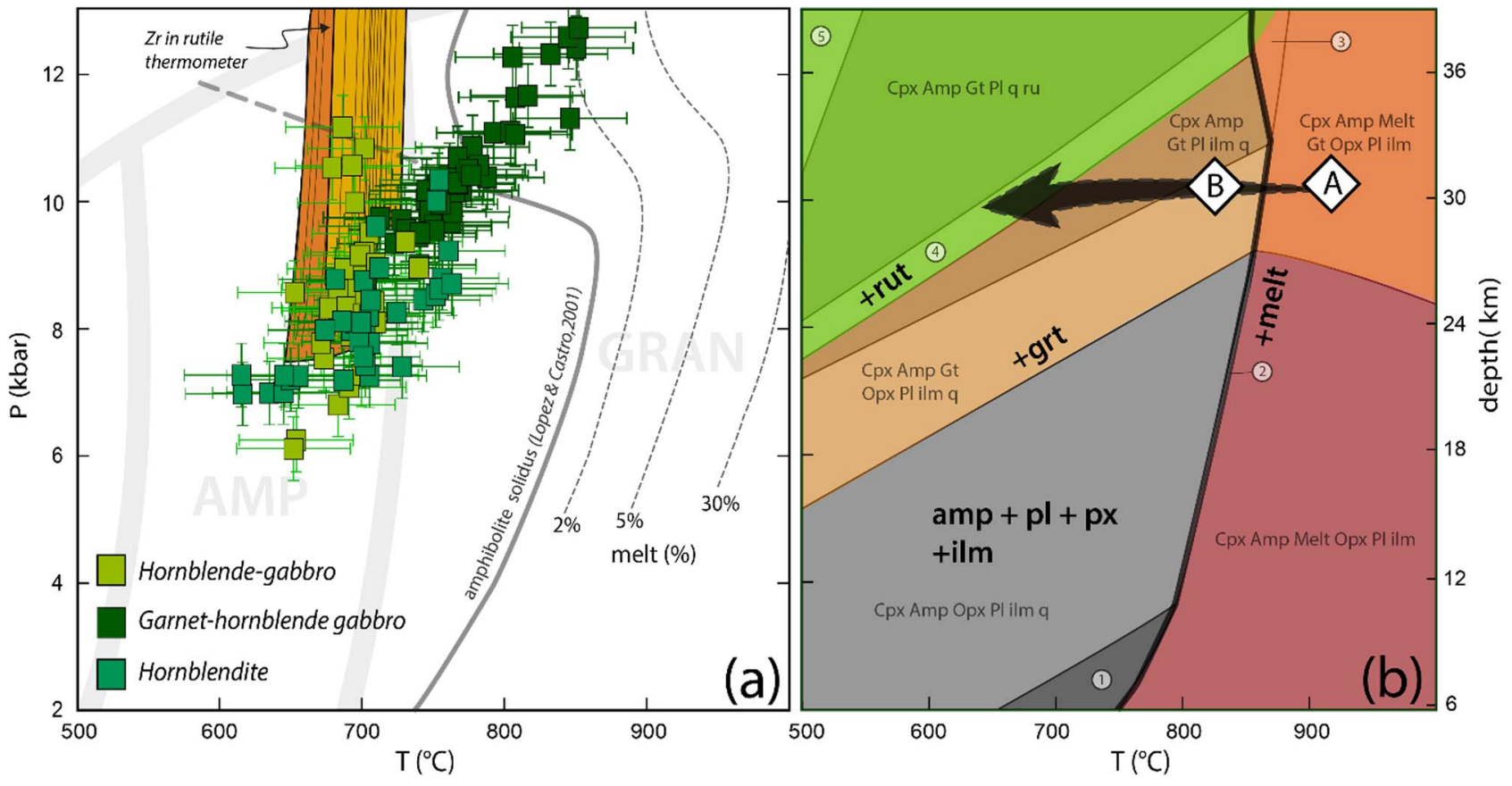

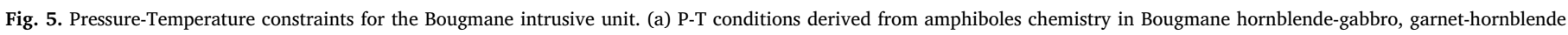

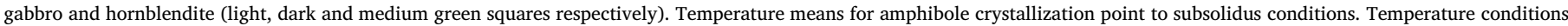

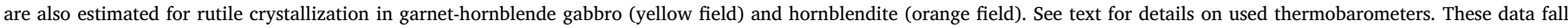

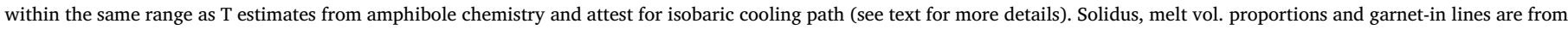

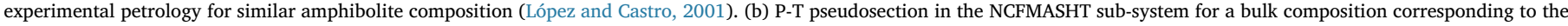

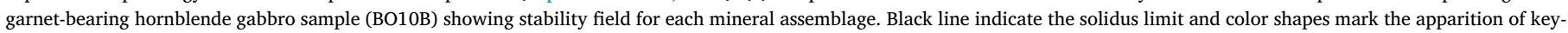

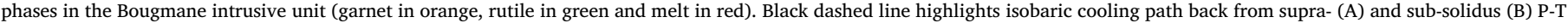
peaks. (For interpretation of the references to color in this figure legend, the reader is referred to the web version of this article.)

$52 \mu \mathrm{m}$ LA-SF-ICP-MS spot size. Temperatures were estimated based on Zr-in-rutile thermometer, using the calibration of Tomkins et al. (2007) for a large pressure range of 5-12 kbar covered by amphibole estimation in the same sample. Calculated temperatures are indiscernible from temperatures estimated from amphibole compositions, spreading from 714 to $736^{\circ} \mathrm{C}$ ( $\pm 22^{\circ} \mathrm{C}$; $3 \%$ error recommended by Ewing et al., 2013) with a weighted mean value of $726^{\circ} \mathrm{C}$ (Fig. 5a).

We also constructed a phase diagram of a Bougmane garnet-bearing hornblende gabbro (BO10B) for which there is no evidence of partial melting but the growth of metamorphic garnet under subsolidus conditions. We consider $1 \mathrm{wt} \%$ of $\mathrm{H}_{2} \mathrm{O}$ on the basis of modal proportion $(\sim 55 \mathrm{vol} \%)$ of amphiboles. The phase diagram was constructed using PerpleX (Connolly, 2005, 2009) in the subsystem with the thermodynamic database of Holland and Powell (1998) revised in November 2002. Solution models for heterogeneous phases are from Newton and Haselton (1981) for plagioclase, White et al. (2014) for garnet, White et al. (2000) for ilmenite, Green et al. (2016) for amphibole, clinopyroxene and tonalitic melt. More details about thermodynamic-based calculations of garnet-bearing mafic rock and granulitic facies can be found in Green et al. (2016). The P-T pseudosection (Fig. 5B) is in agreement with petrological experiments for similar amphibolite bulk composition (Fig. 5A). Indeed, the position of solidus mimics the solidus from petrological experiments and is located around $800{ }^{\circ} \mathrm{C}$. The garnet stability field extends to more than $7-8 \mathrm{kbar}$ of pressure conditions for subsolidus temperature conditions $\left(700-800^{\circ} \mathrm{C}\right)$. The stability field of rutile is subparallel to the 'garnet-in' line but for higher pressure conditions around 9-10 kbar and for similar temperature conditions.

\subsection{Garnet-rich felsic veins/leucosomes}

Garnet-rich leucosomes are found at the direct contact with intrusive hornblendites. They occur as migmatitic patches (coarse garnets and felsic halo) or as garnet-rich felsic veins (Fig. 4). Five samples were analysed by EPMA; four from a garnet-rich felsic vein (ASL17C; BA10, ASL30B and BO24) and another from a garnet-leucosome patch (BA10). Plagioclases from the gabbroic assemblage and in the neosome show comparable albitic compositions (56 $<\mathrm{X}_{\mathrm{Ab}}<78 \mathrm{~mol} \%$ ) and few $\mathrm{K}$ feldspar ( $\mathrm{X}_{\mathrm{Or}}: 80-97 \mathrm{~mol} \%$ ) in the leucosome. Amphiboles from the paleosome located at the contact with neosome show pargasitic compositions similar to those of other hornblende-gabbros of the intrusive unit. They are Mg-rich pargasite and display identical composition to garnet-hornblende gabbro with Ca apfu $>1.7$, Si[iv] ranging from 6.3 to $6.4 \mathrm{apfu}, \mathrm{Na}+\mathrm{K}[\mathrm{A}]>0.56 \mathrm{apfu}$ and $\mathrm{Mg} \#$ ranging between $51 \%$ and $63 \%$. Garnets from both types of garnet-rich leucosome are pyropealmandine in composition with ranges very similar to garnets from garnet-hornblende gabbros (mean garnet cores composition: $\mathrm{X}_{\mathrm{Alm}}$ : 49.4, $\mathrm{X}_{\mathrm{Prp}}: 28.7$; $\mathrm{X}_{\mathrm{Grs}}: 17.4$ and $\mathrm{X}_{\mathrm{Sps}}: 4.5$ ).

In felsic veins, garnets are coarse (pluri-millimetric to centimetric), euhedral and contain several plagioclase inclusions. Chemical profiles of the garnets show homogeneous/flat chemical composition (sample ASL30B: mean $\mathrm{X}_{\mathrm{Alm}}$ : 48.9\%, $\mathrm{X}_{\mathrm{Prp}}$ : 30.1; $\mathrm{X}_{\mathrm{Grs}}: 18.1$ and $\mathrm{X}_{\mathrm{Sps}}$ : 2.9) except at their narrow outer rims where almandine and grossular contents abruptly increase (mean $\mathrm{X}_{\mathrm{Alm}}: 52.0 \%$; $\mathrm{X}_{\mathrm{Grs}}: 17.8$ ) while pyrope content decreases ( $\mathrm{X}_{\mathrm{Prp}}: 27.7 ; \mathrm{X}_{\mathrm{Sps}}: 2.4 ;$ Fig. 6 ), similarly to garnet profiles from garnet-hornblende gabbros.

In migmatitic patches, garnets are as coarser as those found in felsic veins and show subhedral to anhedral shapes. They display heterogeneous chemical profiles (Fig. 6). They consist of a $\sim 1.3 \mathrm{~mm}$ zoned core showing a decreasing $\mathrm{X}_{\mathrm{Alm}}$ and $\mathrm{X}_{\mathrm{Sps}}$ and an increasing $\mathrm{X}_{\mathrm{Prp}}$ and $\mathrm{X}_{\mathrm{Grs}}$ contents. A $\sim 3.9 \mathrm{~mm}$ zoned rim marked by an increase in $\mathrm{X}_{\mathrm{Alm}}$, a decrease in $\mathrm{X}_{\mathrm{Prp}}$ and $\mathrm{X}_{\mathrm{Grs}}$ and a relatively constant $\mathrm{X}_{\mathrm{Sps}}$ contents. The chemical variations measured for this garnet rims are marked by a multistep evolution (Fig. Supp-Mat-1). Each zoning step taken apart is very similar to zonings observed in garnet felsic veins, suggesting that, during their growth, the garnets from migmatitic patches episodically recorded a process similar to that recorded in garnet felsic veins. 


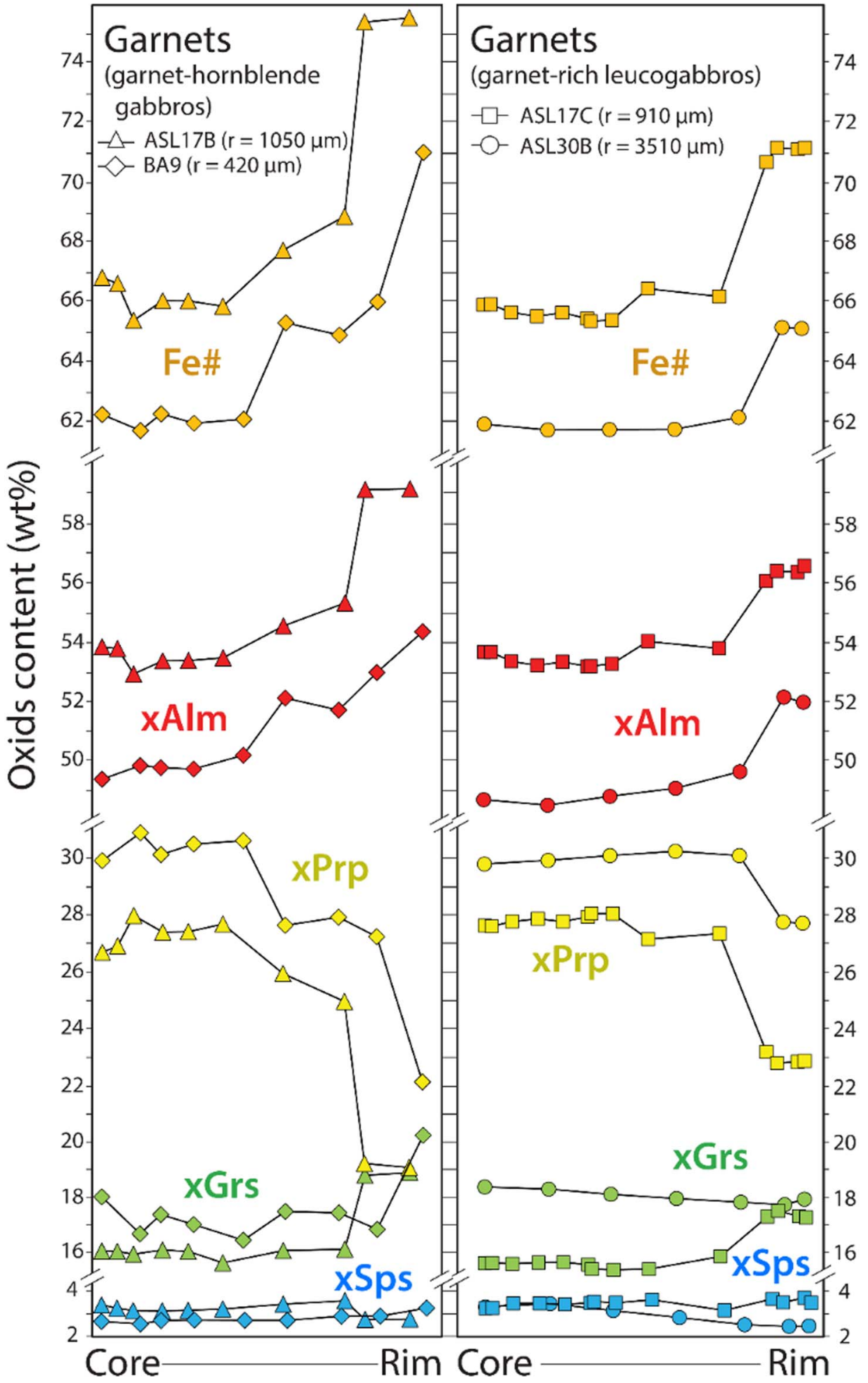

Fig. 6. Core-to-rim compositional profiles of garnets in garnet-hornblende gabbro (left) and garnet-rich leucogabbro (right). Profiles from the four analysed garnets show similar trends marked by a relatively homogeneous core and an abrupt change in composition at the rim (xAlm: almandine; Fe\#: Fe-number; $x$ Grs: grossular; $x$ Prp: pyrope and $x$ Sps: spessartine; $r$ is for garnet radius in $\mu \mathrm{m})$.

\subsection{Hornblendite}

Five samples of hornblendite have been chosen for EPMA analyses (ASL22B; BO10A, ASL24B; BO17; BO33). The cores of the large amphiboles are brownish in PPL (Parallel Polarized Light) and pargasitic in composition (0.52-0.69 (Na $+\mathrm{K})$ [A] apfu for $6.3<\mathrm{Si}_{\text {[iv] }}$ apfu $<6.8$ and $56.3<\mathrm{Mg} \#<79.9 \mathrm{~mol} . \%$ ). Their rims are greenish in PPL, richer in $\mathrm{Si}$ and hornblenditic to actinolitic in composition (0.01-0.48 $(\mathrm{Na}+\mathrm{K})[\mathrm{A}] \quad$ apfu for $\quad 6.9<\mathrm{Si}_{[\text {[iv] }} \quad$ apfu $<8.0 \quad$ and $72.8<\mathrm{Mg} \#<91.1 \mathrm{~mol} . \%$ ), suggesting a partial reequilibration of the primary pargasite. Amphiboles temperatures were estimated using Ti-in-amphibole thermometer which yields weighted mean values of $700 \pm 22^{\circ} \mathrm{C}\left(95 \%\right.$ of confidence; data range: $615-763{ }^{\circ} \mathrm{C}$; Fig. $\left.5 \mathrm{a}\right)$ for brownish cores and of $536 \pm 19^{\circ} \mathrm{C}$ for greenish rims hornblendes (Table B3). Pressure conditions were also estimated using Al content and point to $8.0 \pm 0.4 \mathrm{kbar}$ (with pressure peak at $10.3 \mathrm{kbar}$ ) for the brownish cores (Fig. 5a) which is in the same range as amphiboles from the hornblende-gabbro and hornblendite. The Al-barometer was not applicable to the secondary hornblende giving unrealistic low P conditions (even negative); a fact already observed for other case studies 
(Féménias et al., 2006) and probably due to intense element mobility during this retrograde event. Rutiles in the hornblendite sample (ASL22B) are found as single crystals or as rutile-rich clusters of crystals that grew at amphibole joints. 9 rutiles were analysed for their trace elements. Mean $\mathrm{Zr}$ content is $674 \mathrm{ppm}$ (with $108 \mathrm{ppm}$ as standard deviation). Other trace elements concentrations are available in Table B6. Following the same method as for BO10BB sample, temperatures were calculated for a pressure range between 5 and $12 \mathrm{kbar}$ (Fig. 5) and range between 672 and $714^{\circ} \mathrm{C}\left( \pm 21{ }^{\circ} \mathrm{C} ; 3 \%\right.$ error) with a weighted mean value of $691^{\circ} \mathrm{C}$.

\subsection{Intrusive tonalite}

Two samples (ASL6, ASL35B) were analysed by EPMA. Quartz and plagioclase show anhedral to subhedral rounded shape. Quartz shows slight undulose, generally concentric extinctions. Plagioclase is generally albitic (80-99 $\mathrm{x}_{\mathrm{Ab}} \%$ ). Micas are essentially made of muscovite and chloritized biotite $(-1.47<$ feal $<-0.87$ for $0.08<m g l i<$ 0.34; see Tischendorf et al. (2007) classification: $f e a l=\mathrm{Fe}+\mathrm{Mn}+\mathrm{Ti}-\mathrm{Al}_{[\mathrm{vi}]}$ and $m g l i=\mathrm{Mg}-\mathrm{Li}$ apfu).

\section{Magma composition and geochemical signature}

Geochemical analyses were performed on the different lithologies of the Bougmane intrusive unit (hornblende-gabbro, garnet-bearing gabbro, garnet felsic veins, hornblendite and tonalite) to constrain the nature of the magma pulses building the oceanic arc root and to compare them to plutonic rocks sampled in the middle to lower crust of accreted arcs (i.e. Kohistan, Talkeetna and Amalaoulaou arc) and lavas from active arc settings (i.e. Lesser Antilles, Izu-Bonin and Cascade arcs). The geochemistry of the intrusive tonalitic samples was also used to model the composition of their parental rock. Raw data can be found in Table B1, together with details on sample preparation and analytical procedures in Appendix A.4.

\subsection{Hornblende gabbro and garnet-hornblende gabbro}

Hornblende-gabbros and garnet-bearing hornblende-gabbros show very similar major and trace element bulk rock characteristics (Figs. 7 and 8). They range from primitive, $\left(42-52 \mathrm{wt} \% \mathrm{SiO}_{2}\right)$ to differentiated basaltic compositions with $\mathrm{Mg} \#$ ranging from 45 to 76 (average of 57; $\mathrm{Mg} \#=100 \times \mathrm{MgO} /\left[\mathrm{MgO}+\mathrm{FeO}_{\text {total }}\right]$ on molar basis) and $\mathrm{MgO}$-content ranging from 5.6 to $16.2 \mathrm{wt} \%$. Accordingly, they plot near the tholeiitic and calc-alkaline boundary. They also show low to moderate total alkali $\left(\mathrm{Na}_{2} \mathrm{O}+\mathrm{K}_{2} \mathrm{O}: 1.6-6.1 \mathrm{wt} \%\right)$ and $\mathrm{Ca}$ content (3.5-11.7 wt\% $\mathrm{CaO})$ and rather high Ti contents (0.7-3.1; Fig. 7b-f). The large range of alkali content probably results from alteration during retrograde reactions (e.g., albitization of plagioclase). Al content is generally slightly higher in garnet-bearing samples (9-18 wt\% for hornblende-gabbro and 16-21 wt\% for garnet-bearing gabbro; Fig. 7a) which is also correlated with $\mathrm{Sr}$ content (mean $=370 \mathrm{ppm}$ for hornblende-gabbro against $559 \mathrm{ppm}$ for garnet-bearing mafics) attesting for limited plagioclase accumulation in garnet-bearing samples. Despite large variations in major elements, REE patterns are relatively homogeneous in both lithologies. They show a moderate negative slope from LREE to HREE ([La/Yb $]_{\mathrm{N}}$ mean $\sim 2.1$; Fig. 8) and a slight convex upward pattern for MREE $\left([\mathrm{La} / \mathrm{Nd}]_{\mathrm{N}}: 0.46-0.95\right)$ with decreasing normalized concentrations from $\operatorname{Pr}$ to $\mathrm{La}$, which is less pronounced for three samples: ASL16A, ASL16B, ASL36 (Fig. 8a). Despite the high modal proportion of plagioclase, there is no significant Eu anomaly in hornblende-gabbros $\left(\mathrm{Eu} / \mathrm{Eu}^{*}=[\mathrm{Eu} /(\mathrm{Sm}+\mathrm{Gd}) / 2]_{\mathrm{N}} \sim 1.0\right.$; Fig. 8a and b) except a slight negative anomaly for some garnet-gabbros (Eu/Eu* 0.84-0.94). This suggests that these mafic rocks entirely crystallized from a basaltic melt as commonly observed for melt-like mafic plutonic rocks (i.e. chilled mafic rocks) from middle to lower part of accreted oceanic arc sections (Greene et al., 2006; Dhuime et al., 2009; Berger et al., 2011).
The multi-element diagrams (normalized to N-MORB; values from Sun and McDonough, 1989) show a slight enrichment in LILE (Ba, Rb, K, and $\mathrm{Sr}$ ) and depletion in HFSE (Nb, Ta, and $\mathrm{Zr}$ ) and HREE ( $\mathrm{Yb}$ and $\mathrm{Lu}$ ) relative to N-MORB composition (Fig. 8b-d). These patterns are also marked by a strong negative anomaly in Th, slight negative anomalies in Nb-Ta for most samples and variable anomalies in Zr-Hf (Fig. 8). The similarity in REE and multi-element patterns between hornblendegabbro and garnet-bearing hornblende-gabbro samples suggests that they originated from the same magmatic source and that high pressure mineral assemblage grew subsequently in a closed chemical system. In comparison, garnet-rich felsic veins have similar silica content but very low $\mathrm{Mg \#}(<36.5)$ with high $\mathrm{Al}$ contents $\left(>21 \mathrm{wt} \% \mathrm{Al}_{2} \mathrm{O}_{3}\right)$ compared to host mafic rocks. They show higher LREE contents and much higher HREE contents (Fig. 8c) suggesting accumulation of incongruent garnet in the veins.

\subsection{Hornblendite}

Hornblendites display clustered major and trace elements bulk-rock compositions. They show low-silica contents (between 49.7 and $51.2 \mathrm{wt}$ \%) for very high $\mathrm{Mg \#}$ ranging from 76.2 to $81.7 \%$, high $\mathrm{MgO}$ (14.5-17.3 wt \%) and low $\mathrm{Al}_{2} \mathrm{O}_{3}(<8.6 \mathrm{wt} \%)$. They also show low $\mathrm{Ti}$ compositions $\left(\mathrm{TiO}_{2}<0.64 \mathrm{wt} \%\right)$ and low alkali contents $\left(\mathrm{Na}_{2} \mathrm{O}+\mathrm{K}_{2} \mathrm{O}<1.70 \mathrm{wt} \%\right)$ but high $\mathrm{Ca}(\mathrm{CaO}>10.4 \mathrm{wt} \%)$ (Fig. 7 ). All the hornblendite samples fall in the calk-alkaline field defined by Miyashiro (1973) (Fig. 7f). REE patterns are relatively flat (Fig. 8e) with a slight enrichment in LREE $\left([\mathrm{La} / \mathrm{Lu}]_{\mathrm{N}}>1.61\right)$ and a progressive depletion from $\mathrm{Nd}$ to $\mathrm{Lu}\left([\mathrm{Sm} / \mathrm{Yb}]_{\mathrm{N}}\right.$ between 1.3 and 2.2). Multi-elements patterns show negative anomalies in Nb, Ta and HREE and slight negative anomalies in Ti while significant enrichments in $\mathrm{Rb}, \mathrm{Ba}, \mathrm{Th}$ compared to N-MORB (Fig. 8f). These cumulative fingerprints are in contrast with the intrusive nature of these rocks, a common feature of hornblendites and pyroxenites found in accreted arc roots near the crust to mantle transition (Kohistan arc: Garrido et al., 2006; Dhuime et al., 2007; Jagoutz et al., 2013; Amalaoulaou arc: Berger et al., 2011).

\subsection{Intrusive tonalite}

Intrusive felsic rocks in Bougmane (samples ASL5, ASL6, ASL35p) are K-depleted $\left(<1.40 \mathrm{wt} \% \mathrm{~K}_{2} \mathrm{O}\right.$ ), Na-rich $\left(6.8-7.4 \mathrm{wt} \% \mathrm{Na}_{2} \mathrm{O}\right)$ tonalites (dacitic $\mathrm{SiO}_{2}$ content: $62-71 \mathrm{wt} \%$ ) with very low $\mathrm{FeO}$ and $\mathrm{MgO}$ contents $(<0.6$ and $<0.2$ respectively; Fig. 7 ). The aluminium saturation index $(\mathrm{ASI}=\mathrm{Al} /[\mathrm{Ca}-1.67 \times \mathrm{P}+\mathrm{Na}+\mathrm{K}]$ on molar basis; Shand, 1943) ranges from 1.17 to 1.28 pointing to slightly peraluminous composition. Such felsic magma compositions imply a mafic source after Ellis and Thompson (1986) and Frost et al. (2001). REE contents are low compared to host mafic rocks (Fig. 8g) and LREE are strongly enriched compared to HREE $\left(13<(\mathrm{La} / \mathrm{Lu})_{\mathrm{N}}<26\right)$. The three samples display positive $\mathrm{Eu}$ anomaly $\left(1.6<\mathrm{Eu} / \mathrm{Eu}^{*}<4.4\right)$. Multi-elements patterns are marked by enrichment in LILE elements ( $\mathrm{Rb}, \mathrm{Ba}, \mathrm{Th}, \mathrm{K}$ and $\mathrm{Sr}$ ) compared to N-MORB values (Fig. 8h) and notable Nb-Ta negative anomalies.

\subsection{Host granodioritic gneiss}

Host granodioritic gneisses (samples ASL3, BO19, BZ1A) show dacitic composition, with moderate $\mathrm{K}-\left(1.1-3.3 \mathrm{wt} \% \mathrm{~K}_{2} \mathrm{O}\right.$ ), high Na(5.4-7.2 $\left.\mathrm{wt} \% \mathrm{Na}_{2} \mathrm{O}\right)$ and relatively low Fe- and Mg-contents (1.1-1.9 and $0.7-1.2 \mathrm{wt} \%$ respectively; Fig. 7). Aluminium saturation index spreads from 1.22 to 1.32 , pointing to a peraluminous composition. They portray a major element composition similar to other accreted arc granitoids for equivalent $\mathrm{SiO}_{2}$ values, except for $\mathrm{CaO}$ content which is probably related to $\mathrm{Ca}$ mobilization due to plagioclase albitization (Fig. 7). As for intrusive tonalites, they show highly fractionated REE but with higher $\Sigma$ REE values $\left([\mathrm{La}]_{\mathrm{N}}\right.$ : $\left.11-86 ; 11<[\mathrm{La} / \mathrm{Lu}]_{\mathrm{N}}<50\right)$. Two samples show slightly positive Eu anomaly (Eu/Eu*: 1.3-1.8; 

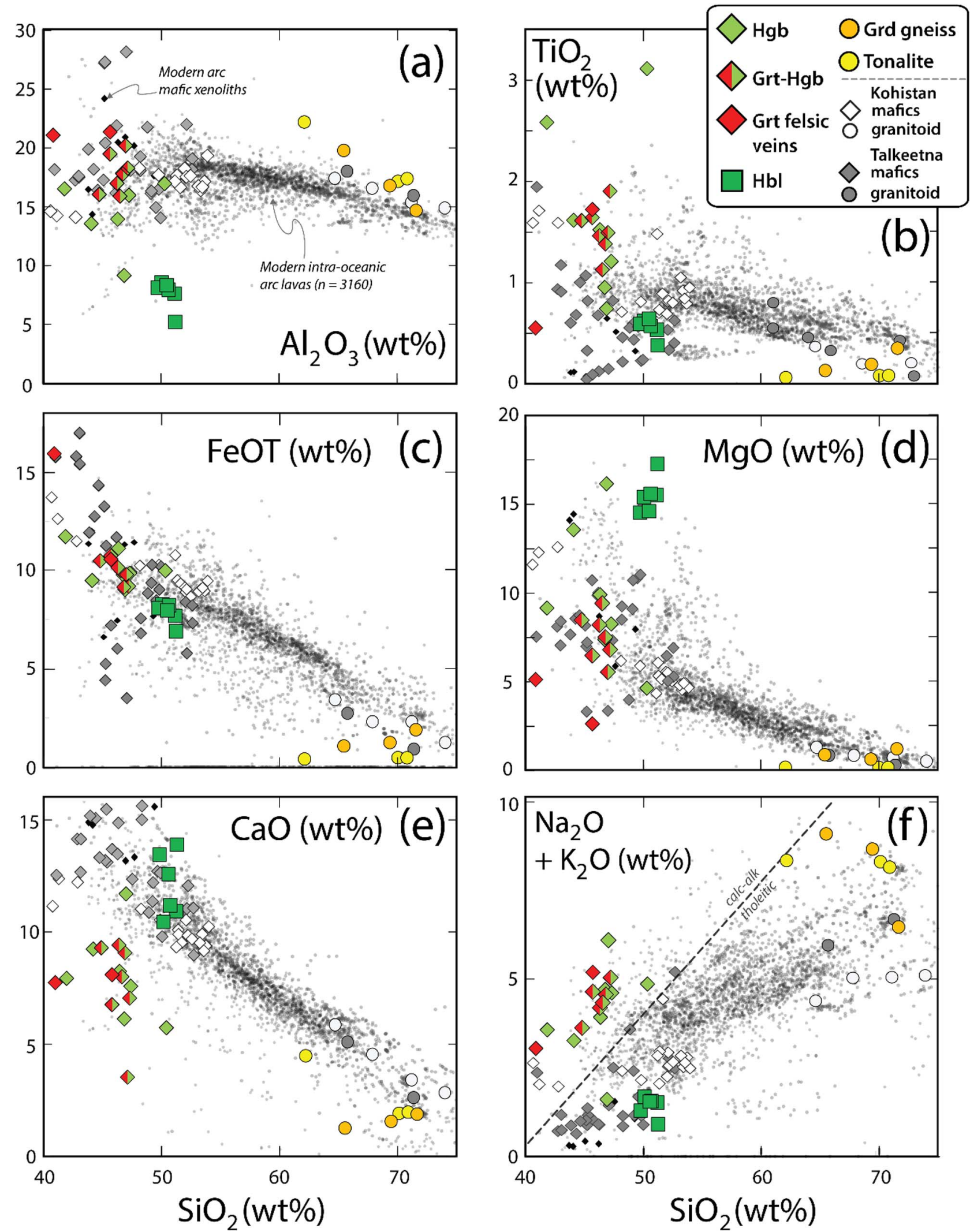

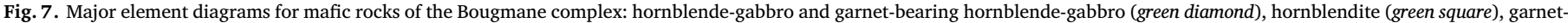

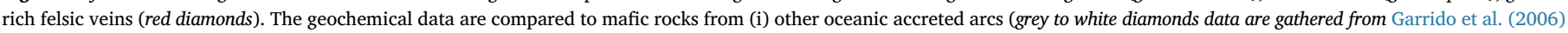

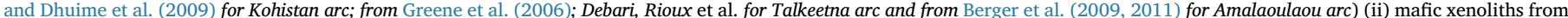

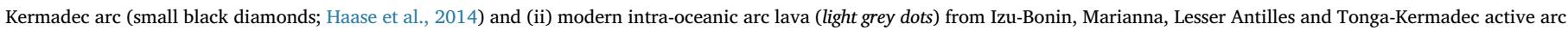
settings (data are gathered from the PetDB database). Tholeiitic Calc-alkaline transition for arc-related rocks (black dashed line) is from Miyashiro (1973). 

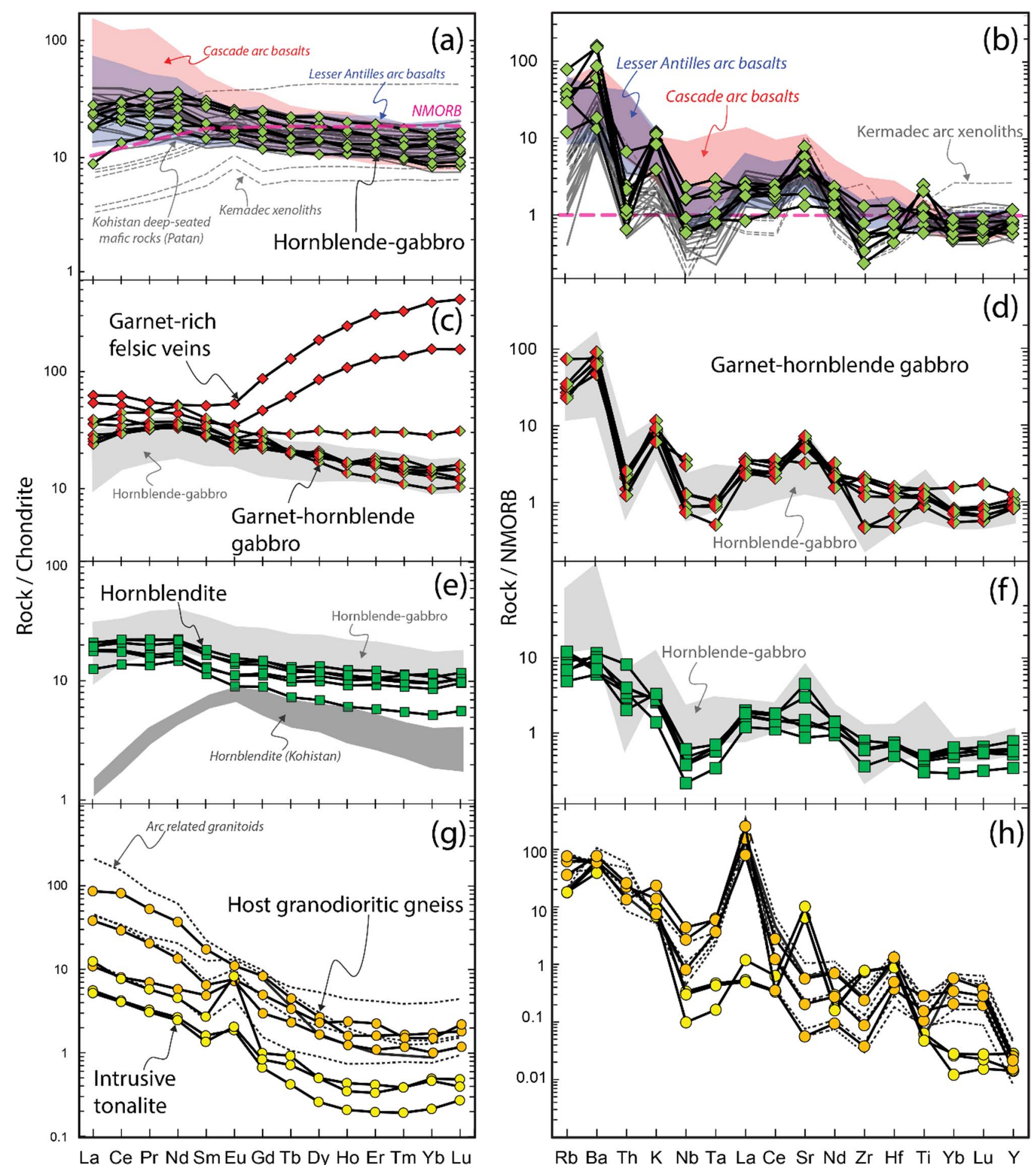

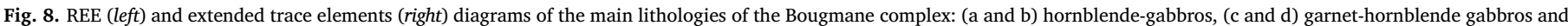

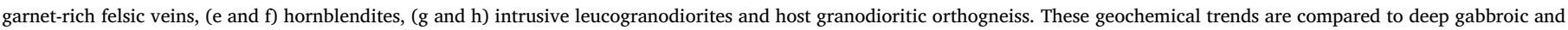

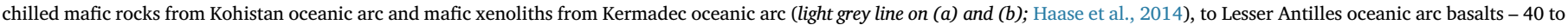

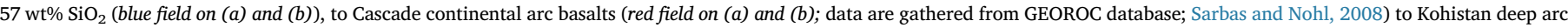

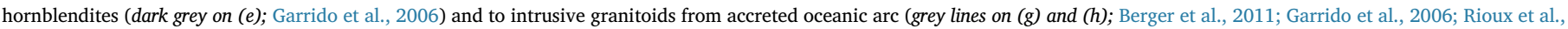

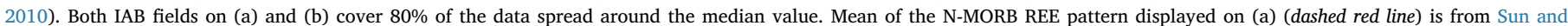

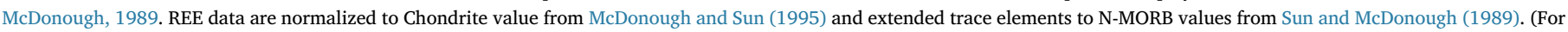
interpretation of the references to color in this figure legend, the reader is referred to the web version of this article.)

Fig. 8g). Their low abundances in discriminant incompatible elements (Ta $<0.17 \mathrm{ppm} ; \mathrm{Rb}<42 \mathrm{ppm} ; \mathrm{Yb}<0.3 \mathrm{ppm} ; \mathrm{Y}<3 \mathrm{ppm}$ and $\mathrm{Nb}<10 \mathrm{ppm}$ ) compared to felsic magmas produced in oceanic ridges (plagiogranite) or post-collisional settings (High-K Calc-alkaline suites;
Pearce et al., 1984) suggest that they are most likely evolved felsic igneous products formed in a volcanic arc setting. Multi-elements patterns show a general enrichment in LILE ( $\mathrm{Rb}, \mathrm{Ba}$, Th and $\mathrm{K}$ ) and LREE, as well as a slight depletion in HFSE (Nb, $\mathrm{Sr}, \mathrm{Zr}$, Ti and $\mathrm{Y}$ ) compared to 

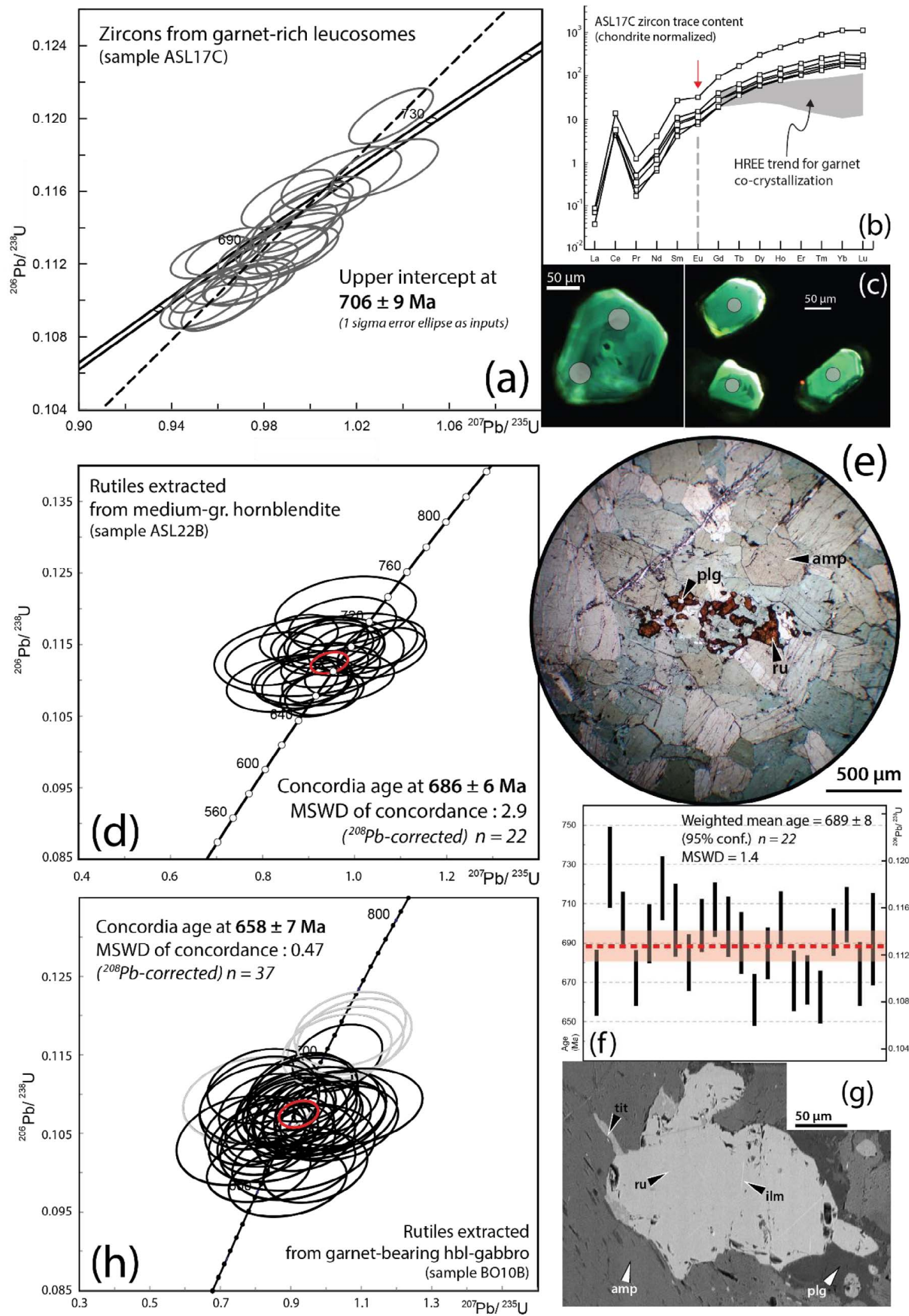

(caption on next page) 


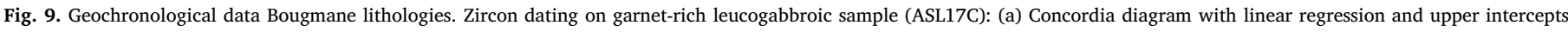

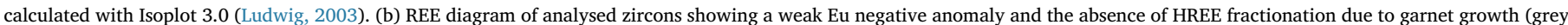

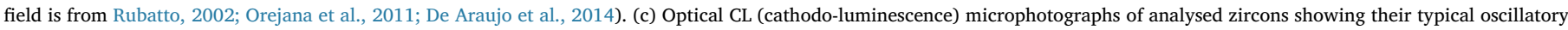

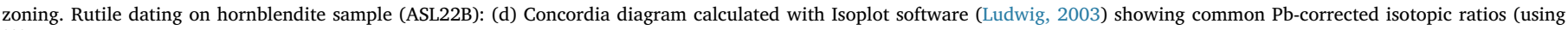

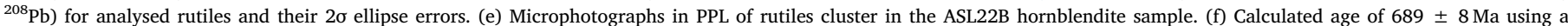

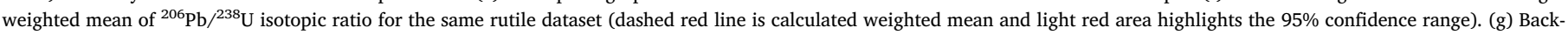

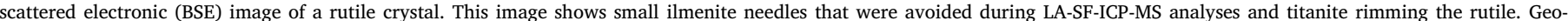

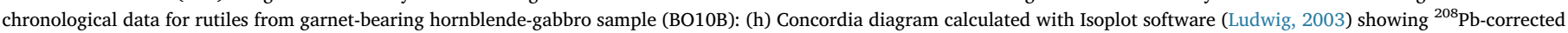
isotopic ratios for analysed rutiles and their $2 \sigma$ ellipse errors. Grey ellipses represent data that were removed for the calculated age due to high Th content.

N-MORB content (Fig. 8h). These trace elements signatures are typical of arc-related magmas, which is also consistent with tonalitic and granodioritic rocks typically forming the middle crust of Talkeetna and Kohistan accreted oceanic arcs (Greene et al., 2006; Garrido et al., 2006; Rioux et al., 2010; Fig. 8h).

\section{In situ U-Pb dating}

Zircons from one sample of the Bougmane garnet-rich leucosome (sample ASL17C; see location on Fig. 2) were extracted via heavy liquid and magnetic separation. Optical cathodoluminescence (CL, see Appendix A.2) images were captured to select spots location for LA-SFICP-MS analyses (see Appendix A.3 for analytical methods and procedure). Sample ASL17C is a garnet-rich leucosome that is typically found near the contact with hornblenditic intrusions (see 'felsic vein' sample on Fig. 4c). The sample comes from the core of the Bougmane intrusive unit at the northern side of the hornblendite massif (UTM29N-WGS84: $\mathrm{X} 725,867 \mathrm{~m}-\mathrm{Y} 33,368,800 \mathrm{~m}$ ). Zircons are $100-210 \mu \mathrm{m}$ long, prismatic, colorless showing euhedral to subhedral shape with rounded edges. They are relatively homogeneous in terms of luminescence and show regular oscillatory zoning (Fig. 9c) suggesting magmatic crystallization (Corfu et al., 2003). Isotopic results point to a Neoproterozoic age and show no inheritance from older Neoproterozoic or Paleoproterozoic grains. The 2-sigma ellipses are slightly spread (MSWD $=0.93$, $n=22$ ) likely due to a lead loss episode. The isotopic data show a clear alignment yielding an upper intercept age (calculated with Isoplot; Ludwig, 2003) of $706 \pm 9$ Ma (Fig. 9a; Table B7). Elemental Th/U ratios are low, ranging between 0.29 and 0.70 with a mean of 0.41 (standard deviation $=0.078$ ). Trace elements concentrations were also determined for five zircons from the same set (Table B5) to constrain the nature of phases in equilibrium during their crystallization. Normalized REE patterns (Fig. 9b) are typical of magmatic zircons with a positive anomaly in Ce and high content in HREE. A slight negative Eu anomaly $\left(0.53<\mathrm{Eu} / \mathrm{Eu}^{*}<0.72\right)$ is observed and no significant fractionation between HREE have been detected $\left([\mathrm{Gd} / \mathrm{Yb}]_{\mathrm{N}}<0.14\right.$; Fig. 9b). Both observations point to crystallization in the presence of plagioclase but without garnet (mean of $[\mathrm{Gd} / \mathrm{Yb}]_{\mathrm{N}}>0.3$; Rubatto, 2002; Orejana et al., 2011). Accordingly, the zircons have crystallized in a typical gabbroic assemblage predating the growth of garnet.

Rutiles from the garnet-hornblende gabbro (sample BO10B; location UTM29N-WGS84: X 724,892 m - Y 3,368,990 m) and the fresh hornblenditic sample (ASL22B; location UTM29N-WGS84: X 726,041 m - Y $3,368,260 \mathrm{~m}$ ) were dated directly on polished thick sections. They were identified using optical microscope in reflected light. Back-scattered electron (BSE) images confirmed their chemical homogeneity and the absence of ilmenite needles in analysed grains.

$B O 1 O B$ is a fresh sample of garnet-bearing hornblende-gabbro (see 'Hgb' sample in Fig. 3f). This rock is not affected by partial melting (no leucosome has been observed). Rutiles are abundantly found in the hornblende-gabbroic matrix and a few rounded inclusions were observed at the rims of garnet porphyroblasts. They are relatively coarse as accessory mineral, with size ranging between 100 and $180 \mu \mathrm{m}$, with rare cleavages and an orange-brown color. In the hornblende-gabbro matrix, they typically form subhedral crystals that grew later at primary crystals joints/boundaries. U-Pb age data were collected by in situ ablation of rutile using a LA-SF-ICP-MS (see Appendix A.3 for laser, sample cell and SF-ICP-MS analytical conditions and isotopic data reduction) and R10 rutile standard (Luvizotto and Zack, 2009; Zack et al., 2011). The amount of common $\mathrm{Pb}\left(\mathrm{Pb}_{\mathrm{c}}\right)$ is variable between each analysed grains. As most of analysed rutiles show very low Th content $(<0.017 \mathrm{ppm})$ and low $\mathrm{Th} / \mathrm{U}$ ratio $(<0.018), \mathrm{Pb}_{\mathrm{c}}$ can be accurately estimated using measured ${ }^{208} \mathrm{~Pb}$ content (Zack et al., 2011) and $\mathrm{Pb}$ isotopic ratios from Stacey and Kramers (1975) crustal model. Results yield a Neoproterozoic age, with most corrected analyses concordant $(n=37)$ and clustered on Concordia (Fig. 9h; Table B8). Calculated concordant age points to $658 \pm 7 \mathrm{Ma} \quad(2 \sigma ; \quad M S W D$ of concordance $=0.47$ ) except for a group of 5 analyses which can be clearly distinguished from the other and points to an older age of $710 \pm 8 \mathrm{Ma}$ (2o; Fig. 9h).

$A S L 22 B$ is a medium-grained hornblendite sample. Such rocks intrude the hornblende-gabbroic rocks and are intimately related to tonalitic melt (see sample 'Hbl' on Fig. 3f). Rutile is frequent and occurs as single crystals or as small clusters (Fig. 9e). They form 100-180 $\mu \mathrm{m}$ crystals that grew at hornblende grain boundaries. Occasionally, small needles of ilmenite have been observed in rutiles (Fig. 9g). They were carefully avoided for LA-SF-ICP-MS analyses by imaging each rutile in BSE. All analysed rutiles show very low Th content $(<0.03 \mathrm{ppm})$ and very low $\mathrm{Th} / \mathrm{U}$ ratio $(<0.004) . \mathrm{Pb}_{\mathrm{c}}$ corrections using ${ }^{208} \mathrm{~Pb}$ can therefore be applied as for BO10B sample (Table B9). Results yield a Neoproterozoic age, with most corrected analyses concordant and moderately spread along the concordia (Fig. 9d) giving an age of $686 \pm 6 \mathrm{Ma}$ (2o; $n=22$; MSWD of concordance $=2.9$; Fig. 9d). Weighted mean age of the ${ }^{206} \mathrm{~Pb} /{ }^{238} \mathrm{U}$ concordant ages were also calculated using Isoplot software (Ludwig, 2003) yielding an age of $689 \pm 8 \mathrm{Ma}$, more consistent with the spreading of the isotopic data (MSWD = 1.4; Fig. 9f).

\section{Sm-Nd isotope geochemistry}

Six samples were chosen for Sm-Nd isotopic analyses, covering the main lithologies of the Bougmane complex (Table B10). The details of the analytical procedures for whole-rock dissolution, chemical separation and mass spectrometry as well as analyses reproducibility are given in the Appendix A.5. Initial $\mathcal{E} N d$ values were calculated based on the available U-Pb zircon ages in the area (the hornblende gabbro, garnethornblende gabbro, hornblendite and tonalite at $700 \mathrm{Ma}$; the granodioritic gneiss at $745 \mathrm{Ma}$; El Hadi et al., 2010; Admou et al., 2013; this study). These initial $\varepsilon N d$ values of all the lithological units of the Bougmane complex are highly positive, ranging between +3.6 and +6.7 (Fig. 10) particularly for the intrusive unit.

\section{Discussion}

\subsection{Chronology of igneous and metamorphic events}

We distinguished two units in the Bougmane complex: (i) hydrous principally mafic rocks which intrude (ii) a bimodal banded orthogneissic unit made of felsic and mafic components (Figs. $2 \mathrm{~b}$ and $3 \mathrm{~b}$ ). The first recognized igneous event (IGN1) is preserved in the latter unit, as gneisses and amphibolites showing relics of mingling structures (Fig. 3b). They can be correlated to orthogneissic massifs (i.e. augen granite, granodioritic gneiss and amphibolite) cropping out in the Tazigzaout and Bou Azzer mine complexes, which are also located in the 


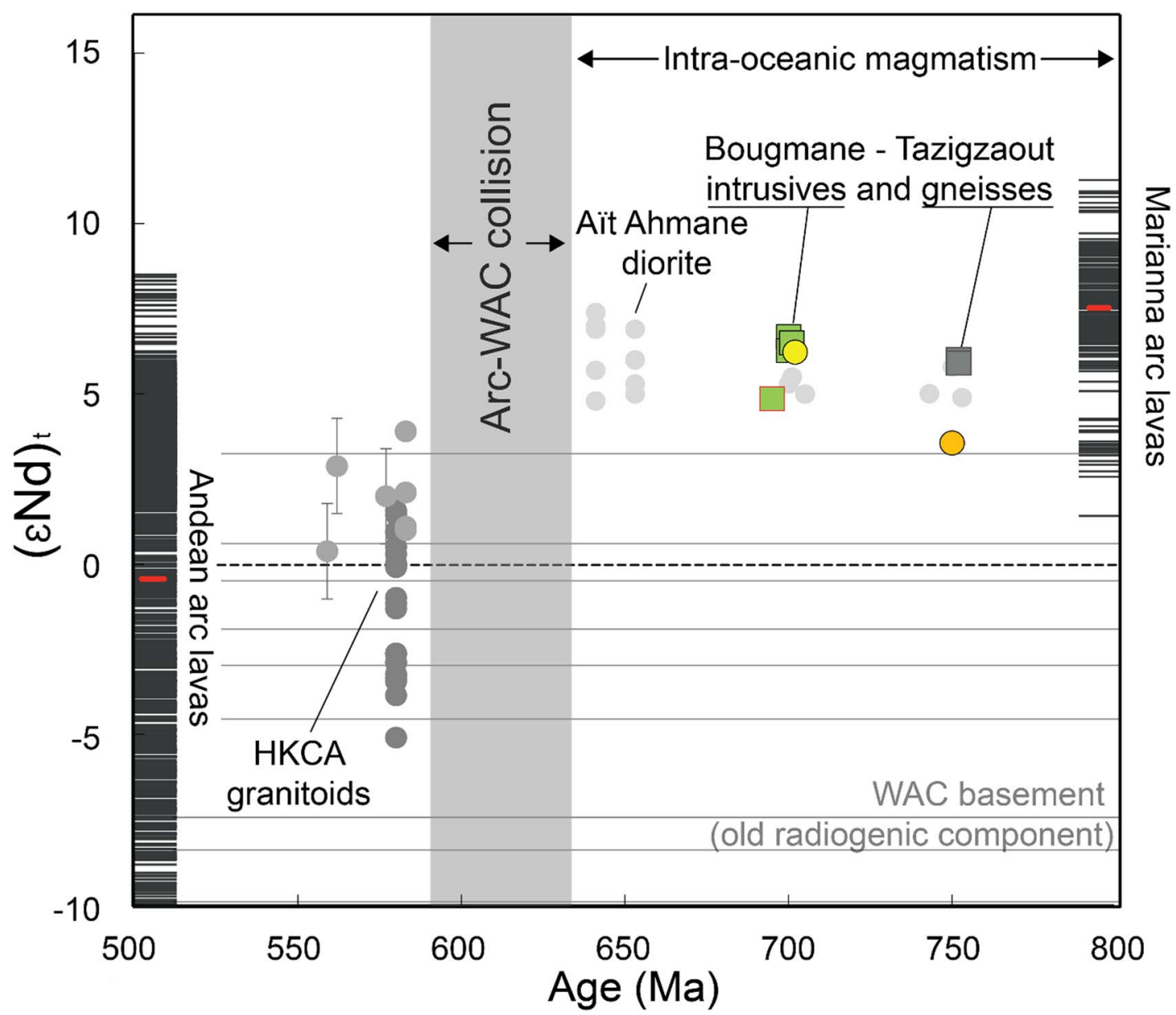

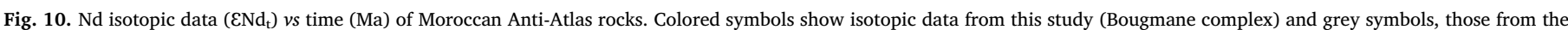

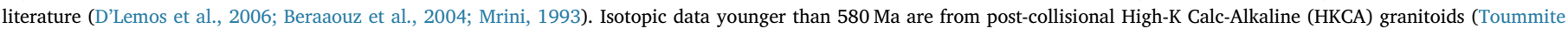

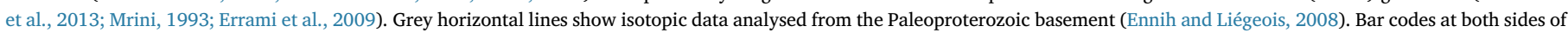

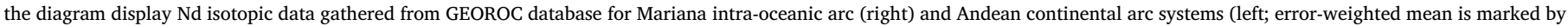
the red tick). (For interpretation of the references to color in this figure legend, the reader is referred to the web version of this article.)

southern part of the Bou Azzer inlier and represent the western extent of the Bougmane complex (Fig. 1b). Formerly interpreted as Paleoproterozoic basement rocks, numerous recent geochronological data attest that these gneissic units are Neoproterozoic in age (760-740 Ma; D'Lemos et al., 2006; El Hadi et al., 2010; Blein et al., 2014). Subsequently to their emplacement, these magmatic rocks were deformed during a first major tectonic and metamorphic event (D1).

The Bougmane hornblende-gabbro, hornblendite and tonalitic rocks form intrusive bodies into the orthogneissic unit. They represent a second igneous event (IGN2) not affected by the D1 deformation phase. The relative chronology between IGN2-related lithologies is difficult to decipher in the field. Admou et al. (2013) interpret the lithological contacts as relics of magmatic layering and/or local magmatic slumps and collapse in a single magmatic chamber. According to structural relationships observed in the field (see Figs. 3e and $f$ and 4), we rather suggest that they reflect the emplacement of multiple magmatic pulses in a relatively short time span and under high temperature conditions (see Section 8.3.1). The IGN-2 induced high grade metamorphic reactions (MET-2) marked by the formation of garnet granulite assemblage in the hydrous mafic rocks. In order to better constrain the timing of magmatic events and high-grade metamorphic overprints observed on the field, we obtained new geochronological U-Pb data on metamorphic garnet-bearing leucosome, hornblende-gabbro and hornblendite from the Bougmane intrusive unit ( $c f$. Section 6 for precise location).

Zircons from the garnet-rich leucosome (ASL17C) gave an age at $706 \pm 9 \mathrm{Ma}$ (Fig. 9a) which is indiscernible from $697 \pm 8 \mathrm{Ma}$ obtained on a garnet-free gabbro in the same area (El Hadi et al., 2010). CL images show a regular oscillatory zoning in most zircons (Fig. 9c) suggesting that they have crystallized during a single growth stage and under magmatic conditions (Corfu et al., 2003). Moreover, in situ trace elements analyses in several zircons of the same set show typical REE spectrum of zircons of magmatic origin (Fig. 9b). Their relatively flat to HREE-enriched pattern indicates that they did not grow in equilibrium with garnet. The REE composition of zircons in garnet-granulitic samples gathered from the literature - and for which garnet-zircon equilibrium is attested - shows indeed lower $[\mathrm{Gd} / \mathrm{Yb}]_{\mathrm{N}}(0.12-0.17$ against > 1.0 in Rubatto, 2002; Bosch et al., 2011; Fig. 9b). Therefore, our data show that they did not reequilibrate with new paragenesis during the high grade metamorphic event (MET-2). The obtained age around $700 \mathrm{Ma}$ - can thus be interpreted as a protolithic age inherited from the intrusion and primary crystallization of the garnet-free hornblende-gabbro (IGN-2) without any influence of subsequent granulitic metamorphic overprint of the MET-2 event.

Common $\mathrm{Pb}$-corrected (based on ${ }^{208} \mathrm{~Pb}$ counts) U-Pb isotopic data of rutiles extracted from the hornblendite located in the core of the Bougmane intrusive unit (ASL22B; Fig. 2a) gave a clustered concordant age of $689 \pm 8 \mathrm{Ma}$ (Fig. 9d), similar within errors to the ages obtained on hornblende gabbros and garnet-rich leucosomes ( $\sim 700 \mathrm{Ma})$. Rutiles are late accessory phases in all Bougmane lithologies, mainly crystallizing at amphibole joints. Closure temperature estimates for $\mathrm{Pb}$ diffusion in rutile range around $600-650{ }^{\circ} \mathrm{C}$ (Cherniak, 2000; Schärer and Labrousse, 2003); accordingly, rutile U-Pb ages can be interpreted as 
cooling ages. The slightly younger age obtained in Bougmane hornblendite is thus consistent with the rutile crystallization shortly after the emplacement and during cooling of the hornblenditic rocks. This is in agreement with zircons protolithic ages as well as with the mingling structures observed in the field. It suggests that their respective parental magmas were emplaced during a short time span during a single major magmatic episode (IGN2).

The garnet-hornblende gabbro (BO10B; Fig. 2a) yielded a younger $\mathrm{U}-\mathrm{Pb}$ rutile age of $658 \pm 8 \mathrm{Ma}$ (compared to zircon and hornblendite rutile ages) except for 5 analyses that point to an older age of $710 \pm 8 \mathrm{Ma}$ (Fig. $9 \mathrm{~h}$ ). Rutiles, interpreted as younger sub-solidus mineral phase, crystallized at pargasite joints and as inclusions in porphyroblastic garnet rims. The older rutile $\mathrm{U}-\mathrm{Pb}$ ages fall within the same range as $\mathrm{U}-\mathrm{Pb}$ dating obtained on protolithic zircons of the IGN-2 magmatic event mentioned above $(\sim 700 \mathrm{Ma})$. They likely represent relics of a first growth of rutile during cooling path after the IGN-2 event. The younger rutile age ( $\sim 660 \mathrm{Ma})$ can be interpreted as: (i) the subsequent growth of new rutile grains, (ii) the end of intracrystalline diffusion in pre-existing rutile grain under subsolidus conditions or (iii) the record of an isotopic reset due to a thermal perturbation likely related to a third magmatic pulse. There is no microtextural evidence of subsequent growth of rutiles in the hornblende-gabbroic sample which makes the first hypothesis unlikely. However, the absence of younger isotopic age for the hornblendite rutiles is more consistent with a local increase in temperature that affected the BO10B hornblende-gabbro only. In this scheme, a larger-scale thermal event having affected the entire Bougmane complex seems less plausible. Although no intrusive rocks contemporaneous to the thermal resetting of rutiles have been found in the Bougmane intrusive unit (south of the Bou Azzer inlier), the 660-650 Ma age range is well known and constrained in the PanAfrican oceanic arc igneous activity and marked by the emplacement of dioritic plutons within the Bou Azzer inlier (Inglis et al., 2005; D’Lemos et al., 2006; Walsh et al., 2012; Admou et al., 2013; Triantafyllou et al., 2016). We thus suggest that this third igneous event (IGN3) could have locally perturbed the thermal evolution of IGN2 rocks either due to large scale heat diffusion or to the presence of small hidden (not outcropping) diorites bodies at Bougmane.

\subsection{The Bougmane complex is the piece of an oceanic paleo-arc}

The rocks from the Bougmane complex show a bimodal geochemical distribution (Fig. 7). Their trace elements contents are marked by several chemical markers attributed to hydrous magma in subduction-related environments (e.g., Berly et al., 2006; Dhuime et al., 2007) with enrichments in LILE (Ba, Rb, K, and Sr) and variable depletions in HFSE $(\mathrm{Nb}, \mathrm{Ta}$ and $\mathrm{Zr}$ ) and HREE ( $\mathrm{Yb}$ and $\mathrm{Lu}$ ) relative to N-MORB composition (Fig. 8b-d).

The Bougmane intrusive mafic rocks show similar geochemical fingerprint as island arc tholeiites (IAT; bell-shaped REE patterns, [La/ $\mathrm{Yb}]_{\mathrm{N}}$ mean $\sim 2.1$ ). They have also been reported as metagabbroic rocks in the lower and middle part of accreted arc sections (Dostal et al., 1994; Dhuime et al., 2009; Berger et al., 2011). Despite the high modal abundance of plagioclase, the absence of Eu anomaly attests that these mafic rocks did not accumulate plagioclase. Also their chemical homogeneity through the intrusive unit suggest that they formed from a common parental arc magma and that they were not affected by crystal accumulation processes. Indeed, their REE trends are similar to hydrous gabbroic rocks sampled in the middle to deep sections of Jijal and Talkeetna oceanic paleo-arcs (Greene et al., 2006; Garrido et al., 2006) and interpreted as melt-like mafic rocks.

The systematic association of hornblendite and tonalitic bodies is obvious on the geological map (Fig. 2) but also clearly identified from field observations, arguing for a magmagenetic link between both rock types (see Section 8.3.2). According to geochronological data plus field evidences, hornblendite and tonalite are products of a primary magma that intruded the hornblende-gabbros and probably crystallized in a short period of time ( $<20 \mathrm{Ma}$ ) during the second igneous event (IGN2 $700 \mathrm{Ma}$ ). Hornblendites are a common lithology formed in deep to midcrustal section of arcs. They commonly represent cumulative parts of crystallizing/cooling hydrous arc basalts. In comparison to lower crustal hornblendites from accreted arcs, the Bougmane samples display similar MgO values but higher REE content with flatter REE patterns. Nonetheless, the REE and multi-element patterns are parallel to those found in oceanic arc basalts from active arc settings (Lesser Antilles and Marianna IAB; Fig. 8e and f) and are locally similar to Bougmane hornblende-gabbroic trace elements trends albeit lower concentrations. This suggests that both intrusive rocks probably crystallized from similar arc melts.

The high positive $\varepsilon \mathrm{Nd}_{\mathrm{t}}$ (ranging between +3.6 and +6.7 with a mean at +5.7 ; Fig. 10) values for all the igneous rocks from the gneissic (IGN1) and the intrusive units (IGN2) of the Bougmane complex are very close to depleted mantle signature during Cryogenian times (Middle Neoproterozoic with a $\varepsilon \mathrm{Nd}_{\mathrm{t}}$ around +6 ; Salters and Stracke, 2004). These isotopic data attest that their respective parental magmas were extracted from a depleted mantle source (DePaolo and Wasserburg, 1977) and prove that these magmas did not assimilate rocks from the WAC Paleoproteroozoic basement, characterized by largely negative ENd (see Fig. 10; Ennih and Liégeois, 2008). Within the Pan-African belt, such high positive $\mathcal{E N d}_{\mathrm{t}}$ values are also characteristic of lavas and cumulates from the Neoproterozoic intra-oceanic arc complexes (Caby et al., 1989; Caby, 2003; Thomas et al., 2002; Berger et al., 2011). Compared to $\mathrm{ENd}_{\mathrm{t}}$ values measured on lavas from active arc settings like the Izu-Bonin-Marianna intra-oceanic arcs (ranging +4 and +9; Stern et al., 2003 and Georoc database) and the Andean continental arc (from -10 to +7 ; Georoc database; Fig. 10), the highly positive and clustered $\varepsilon \mathrm{Nd}_{\mathrm{t}}$ values for all the Bougmane igneous and meta-igneous rocks, plus their typical subduction signature, are consistent with an intra-oceanic arc environment. In the Moroccan PanAfrican belt, the first marker of the involvement of old crustal units in the formation of igneous bodies is marked by the emplacement of postcollisional high-K calk-alkaline series (Assarag, Amassine and Bleïda suites) in the Sirwa and Bou Azzer inlier, as well as the emplacement of granitic plutons in the Saghro dated between 580 and 540 Ma. All these rock show $\mathcal{E N d}_{\mathrm{t}}$ comprised between +4 and -5 (Mrini, 1993; Beraaouz et al., 2004; Errami et al., 2009; Toummite et al., 2013; Fig. 10) and attest that the radiogenic West African Craton lithosphere influenced or generated the post-580 Ma magmas. Accordingly, we conclude that continental collision and total closure of oceanic domains occurred within the 630-580 Ma age range (Gasquet et al., 2008).

\subsection{Differentiation processes deep inside the oceanic arc}

\subsubsection{Garnet growth in the Bougmane arc root during dehydration induced} by intrusive magma

The occurrence of garnet into mafics (gabbro) and ultramafics (pyroxenite) is commonly observed in the lower section of paleo-arcs (e.g., Burg et al., 1998; Garrido et al., 2006; Berger et al., 2009, 2011) and suspected in modern arc settings (Martin et al., 2005; Moyen and Martin, 2012; Lee and Lackey, 2015). Garnet-bearing mafics are more typical in mature arcs characterized by a sufficient crustal thickness to allow its stability in basic rocks ( $>30 \mathrm{~km}$; Stern, 2010). Garnet-rich assemblages increase the bulk density of massifs and can involve gravity instabilities which can lead to crustal delamination and foundering back into the lithospheric mantle at the root of IOAS (e.g., Debari and Greene, 2011; Jagoutz and Behn, 2013). There are two main petrogenetic models to explain the formation of garnet and related P-T conditions: (i) As mafic-ultramafic cumulates. Garnet-rich mafic rock can be a magmatic product that is stocked in the cumulative part at the base of the arc. Such interpretation has been proposed to explain garnetclinopyroxenite lenses found at the root of the Kohistan paleo-arc (Jagoutz and Behn, 2013) and was also reproduced by experimental petrology (Müntener and Ulmer, 2006; Alonso-Perez et al., 2009); (ii) 
As a dehydration/granulitic product. The garnet growth in the mafic arc rock can be due to high pressure dehydration reactions. A dehydration front has been described in the deep section of the Kohistan paleo-arc and is interpreted as garnet-granulite formed by increase in temperature (Annen et al., 2006; Garrido et al., 2006; Otamendi et al., 2008; Berger et al., 2011; Stowell et al., 2014). Such HP assemblages are also well reproduced in petrological experiments for similar P-T conditions and similar amphibolitic chemical bulk compositions (Rapp and Watson, 1995; López and Castro, 2001; Johannes and Holtz, 2012).

In the Bougmane intrusive unit, garnets consist of a metamorphic phase as attested by their porphyroblastic microtexture and by the similarity of major and trace chemical composition between garnetbearing and garnet-free mafic rocks (Figs. 7 and 8). Their typical occurrences on the field within mafic rocks (or as incongruent phase in leucosome veins) located near and at the contact of intruding hornblendite (Fig. 3e and f) suggests that they are the result of subsolidus dehydration reactions (or suprasolidus dehydration melting). According to our P-T pseudosection (Fig. 5b) and experimental petrology for similar bulk rock composition (Rapp and Watson, 1995; López and Castro, 2001; Johannes and Holtz, 2012), such reactions occur under high pressure conditions ( $>8 \mathrm{kbar}$ ). The suspected increase in temperature is also consistent with chemical profiles of constitutive garnets with flat pattern at cores and abrupt variations at rims (Fig. 7). Similar garnet patterns have been reported by Ringuette et al. (1999) in garnetgranulite facies from the deep section of the Kohistan arc (Jijal sequence). Their flat patterns in the core are interpreted as high temperature reequilibration or a long timespan at subsolidus conditions that would allow efficient intracrystalline chemical diffusion (see Caddick et al., 2010; Konopásek and Caddick, 2016). After reaching the peak temperature, garnet-bearing rocks in Bougmane underwent an HP isobaric cooling. As suggested by Spear and Peacock (1989) and Ringuette et al. (1999) for comparable chemical systems, an abrupt increase in grossular content can either be interpreted as pressure increase or as a nearly isobaric cooling in such environment. This is also supported by the chemical composition of pargasitic amphibole. According to empirical thermobarometry (Fig. 5a), Al-rich pargasites have been reequilibrated under the same high pressure ranges ( $>8 \mathrm{kbar}$ ) and subsolidus temperature $\left(650-850^{\circ} \mathrm{C}\right)$. The growth of abundant accessory rutiles in Bougmane hornblende-(garnet) gabbro is also a marker of HP metamorphic reactions. According to experimental data (Ernst and Liu, 1998) and recent phase diagram calculation (Palin et al., 2016 and this study; Fig. 5b) for similar bulk rock composition, rutile is stable at relatively high pressure conditions ( $>10 \mathrm{kbar}$ ) for medium to high temperature ranges $\left(>700^{\circ} \mathrm{C}\right.$; Fig. $\left.5 \mathrm{~b}\right)$. Ilmenite becomes the stable Ti-rich phase at similar temperature conditions but lower pressure conditions ( $<10 \mathrm{kbar}$; Fig. 5b). Calculated temperatures for garnet-hornblende gabbros rutiles $\left(\sim 720^{\circ} \mathrm{C}\right.$; Fig. $\left.5 \mathrm{a}\right)$ as well as their microtextural relation (at crystal joints and as inclusions in the garnets rims) suggest that these rocks underwent an isobaric cooling path after the emplacement of hornblendite-related parental magma under sufficiently high pressure conditions to maintain rutile stability. These new data show that the Bougmane oceanic arc reached a significant crustal thickness (minimum $30-35 \mathrm{~km}$ ) before and/or during the $700 \mathrm{Ma}$ magmatic pulse. The dehydration and dehydration-melting reactions evidence that the deep arc section underwent successive magmatic pulses marked by HP isobaric 'back and forth' temperature paths near the Bougmane mafics hydrated solidus.

\subsubsection{The genesis of felsic magmas in deep section of Bougmane arc}

Arc felsic magmas can consist of: (i) a residual melt formed after fractional crystallization of a primary hydrous arc basalt (Grove et al., 2003; MacPherson et al., 2006) or (ii) a melt generated by partial melting of a pre-existing mafic protolith (Chappell and White, 2001; Annen et al., 2006; Otamendi et al., 2008). Bougmane tonalitic magmas show typical arc signature (i.e. enrichment in LILE; moderate Rb: $10 \mathrm{ppm}$; low $\mathrm{Y}<0.8 \mathrm{ppm}, \mathrm{Yb}<0.09 \mathrm{ppm}, \mathrm{Nb}<0.8 \mathrm{ppm}$ and
Ta $<0.06$ ppm; Pearce et al., 1984) and mimic geochemical trends for major and trace elements of felsic magmas that were produced in Phanerozoic paleo-arc settings (Figs. 7 and 8; Garrido et al., 2006; Greene et al., 2006; Rioux et al., 2010). They also show a typical adakitic signature (low HREE: $\mathrm{Yb}<0.1 \mathrm{ppm}$; low $\mathrm{Y}<0.8 \mathrm{ppm}$; $13<[\mathrm{La} / \mathrm{Lu}]_{\mathrm{N}}<26$; high $\mathrm{Sr}>570 \mathrm{ppm}$; Martin, 1999). Adakites are widely thought to be formed by partial melting of oceanic mafic rocks in the stability field of eclogite or garnet amphibolite (i.e. 'arclogite'; e.g., Defant and Drummond, 1990; Morris, 1995; Martin, 1999; Beate et al., 2001; Condie, 2005; Lee and Anderson, 2015). The low Mg content of Bougmane tonalite $\left(\mathrm{MgO}<0.2 \mathrm{wt} \% ; \mathrm{Fe}_{2} \mathrm{O}_{3}<0.6 \mathrm{wt} \%\right)$ precludes interaction of such deep melt with $\mathrm{Fe}-\mathrm{Mg}$ rich minerals (i.e. olivine) from the subarc lithospheric mantle and thus, rather suggests an intra-crustal process.

Two intra-arc magmagenetic processes have been tested here to explain the formation of Bougmane tonalites: (i) HP fractional crystallization of a hydrous IAB or by (ii) HP partial melting of hydrous garnetbearing mafic rocks at the base of the arc or of eclogitic rocks from the subducting slab. Modelling fractional crystallization of garnet-clinopyroxene assemblages from an island arc basalt was unable to produce a residual melt with such low $\Sigma$ REE content and generally imply more than $60-70 \%$ of cumulate. In addition, the lack of magmas with intermediate composition related to the Bougmane intrusive tonalites (Fig. 7) is also less consistent with an origin by fractional crystallization. Batch (Shaw, 1970), fractional (Allegre and Minster, 1978) and disequilibrium (Sawyer, 1991) partial melting equations were used to calculate the REE composition of modelled melt (equations' definitions can be found in Appendix B11). The disequilibrium melting model has been typically developed for migmatitic structures for which field relations between the melt (leucosome), the residue (melanosome) and the protolith (paleosome) were clearly identified (e.g., Sawyer, 1991; Janák et al., 2001; Lee and Cho, 2013) and for which the chemical equilibrium between the melt and solid residue is not attained during the partial melting; marked by leucosome with very low contents of elements generally associated with very slow rates of diffusion which includes REE, Nb, Ta and Th (Sawyer, 1991; Watt et al., 1996; Hasalová et al., 2008; McLeod et al., 2012; Lee and Cho, 2013). Two distinct protoliths are tested here: (i) the Bougmane garnet-hornblende gabbro (amphibole/garnet: $60+$ plagioclase: 40 vol\%) and (ii) the mean of deep cumulative gabbronorites (clinopyroxene: $40+$ amphibole: $20+$ plagioclase: $40 \mathrm{vol} \%$ ) gathered from the Talkeetna oceanic paleo-arc (Greene et al., 2006). Mineral/felsic melt partition coefficients are from Taylor et al. (2015) for garnet, from Dunn and Sen (1994) for plagioclase, from Klein et al. (1997) for amphibole, from Hauri et al. (1994) for clinopyroxene. Orthopyroxene was not included in the calculation because of its low weight in the calculation due to very low $\mathrm{K}_{\mathrm{D}}$ values. Modelled melt REE abundance were then fitted respectively to tonalitic melt sampled in Bougmane by varying equations' parameters (F, P, X) and using least-squares fitting solver (Weisstein, 2002; see detailed results in Appendix B11).

Starting with cumulative gabbronorite as a protolith, REE compositions of Bougmane tonalites and modelled melts using fractional melting equation showed good correlation coefficient (C. C. $\sim 0.98$ ). Plagioclase is the main reactant phase as suggested by very high positive Eu anomaly observed in Bougmane tonalites. Clinopyroxene is the main residual phase while garnet is an incongruent phase products of the partial melting reaction. LREE are mainly controlled by melt fraction $\mathrm{F}$ (ranging between $5 \%$ and $11 \%$ to cover all the samples; Fig. 11b). HREE abundances are essentially controlled by a proportion of garnet as a residual product of partial melting (5-30 vol\% of garnet; Fig. 10b). This model would imply an external protolith to the system characterized by very low REE content. Such a protolith is not observed on the field but it could have formed and partially molten deeper in the arc section, generating felsic magma that were collected at a higher crustal level.

Starting with Bougmane garnet-hornblende gabbro as a protolith, we were not able to reproduce the same melt composition using fractional 

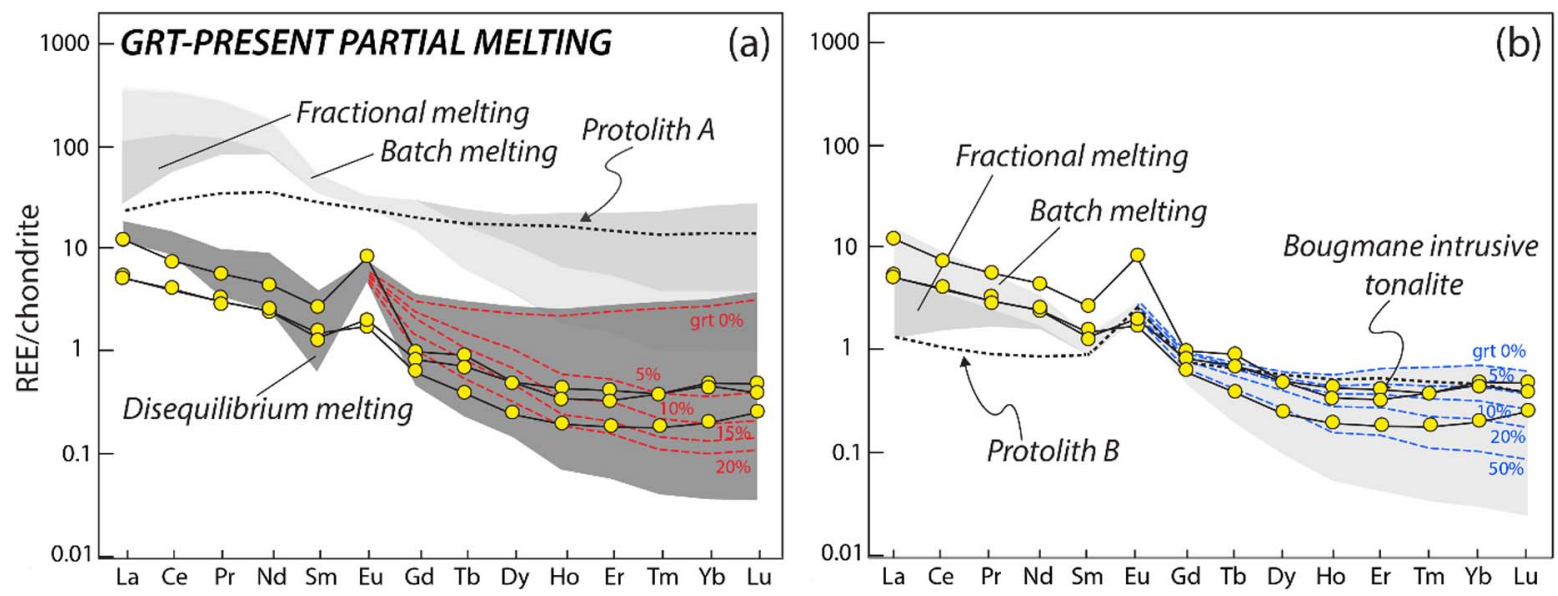

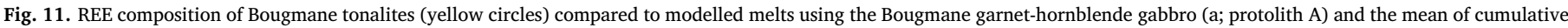

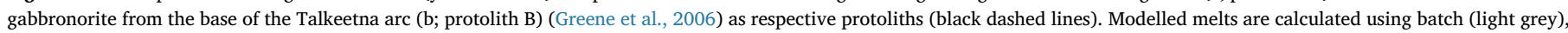

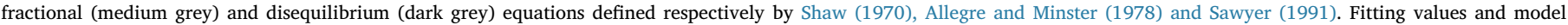
constraints (i.e. modal composition, partition coefficients) are detailed in the discussion (see text) and numerical results can be found in the Appendix B11.

or batch melting equations. Indeed, in both models, the $\Sigma$ REE values are still 10-20 times higher than for Bougmane tonalites. However, using disequilibrium melting equation, we found very acceptable fitting values (C.C. 0.96) and coherent partial melting parameters (see Appendix B11). Plagioclase is the main reactant phase with few clinopyroxene. The HREE abundance is mainly controlled by the amount of garnet in the protolith (best fit: $5-20$ vol\% of garnet; Fig. 11a) which is consistent with the mafic protolithic sample used in the model. The disequilibrium melting hypothesis is more consistent with the specific signature of Bougmane tonalite. It implies a more realistic in situ mechanism of partial melting of the Bougmane garnet-hornblende gabbro. This option also requires efficient melt extraction as suggested by the disequilibrium model but also by the absence of clear migmatitic structure on the field.

\subsection{Geodynamic implications and comparison with the evolution of other intra-oceanic arcs}

The Bougmane arc complex recorded at least three successive magmatic pulses (IGN1-2-3) and a major tectonic event (D1) spanning over $120 \mathrm{Ma}$ during the Cryogenian (cf. Fig. 12). This new study, combined with previous works on Moroccan arc remnants, allows us to propose a geodynamic scenario for the evolution of the Neoproterozoic arc complexes in the Moroccan Pan-African belt and to discuss its relevance through our knowledge of arc growth processes in modern IOAS and Phanerozoic paleo-arcs.

In the Bou Azzer window, the 760-730 Ma igneous event (IGN1; Fig. 12A) has been recorded in Bougmane but also in the Tazigzaout and Bou Azzer Mine gneissic units (D'Lemos et al., 2006; Fig. 1b). In the Sirwa window, gneissic oceanic arc remnants, namely the Tachakoucht and Tourtit gneisses, show comparable protolithic ages ( $\sim 745-730 \mathrm{Ma}$; Thomas et al., 2004; Triantafyllou et al., 2016) and similarly to the Bougmane case study, played the role of hosting units for subsequent arc-related magmatism (Triantafyllou et al., 2016). Intermediate magmas produced at this stage ( $c f$. Bougmane and Tazigzaout granodiorites) are exempt of element anomalies (HREE) that would require fractionation by HP assemblages (i.e. garnet-rutile) and hence, a significant crustal thickness of the arc. This first episode of arc construction is also accompanied by the formation of a back-arc spreading centre, represented in the Sirwa window by the Khzama ophiolite dated at $762 \mathrm{Ma}$ (Samson et al., 2004). Even if no radiometric age has been provided yet, the Bou Azzer ophiolite most likely belongs to the same back-arc marginal setting based on their similar subduction geochemical affinity (Bodinier et al., 1984; Ahmed et al., 2005) as well as their gneissic structures (Bousquet et al., 2008; El Hadi et al., 2010) that are also recorded by the arc gneissic units. Therefore, we suggest that at this stage, the Moroccan oceanic arc grew by accumulating 20-30 Ma of arc magma supply, likely without reaching a mature arc architecture. During this period, intermediate composition magmas were generated (by anatexis and/or intra-crustal differentiation) and formed a typical middle crust where evolved igneous products were collected (Debari and Greene, 2011). This scheme shares many similarities with Scotia/ South Sandwich and Mariana oceanic arc systems. Both IOAS show small and moderate timespans of their respective arc magmatic activity ( $\sim 10 \mathrm{Ma}$ and $45 \mathrm{Ma}$ respectively; Dimalanta et al., 2002; Larter et al., 2003; Leat and Larter, 2003) and are marked by a moderate arc thickness (20 and 18-20 km respectively; Larter et al., 2003; Takahashi et al., 2007; Calvert et al., 2008). They are both characterized by intermediate to felsic mid-crustal layers evidenced by low seismic velocities (Leat and Larter, 2003; Takahashi et al., 2009) as well as an active back-arc spreading centre probably resulting from a steeply inclined subducting slab and/or by a low coupling of involved plates in the oceanic subduction (e.g., Hamilton, 2007; Gerya and Meilick, 2011).

A major tectonic and metamorphic episode (D1) strictly affected these IGN1 arc units and therefore, can be restricted in time between the youngest protolithic age dated around $730 \mathrm{Ma}$ (Triantafyllou et al., 2016) and the oldest age of undeformed igneous rocks emplaced during the second magmatic event IGN2 around $700 \mathrm{Ma}$ (D'lemos et al., 2006; this study). In the Sirwa window, this episode is responsible for the burying of Tachakoucht meta-andesites up to $8 \mathrm{kbar}$ of pressure conditions and the southward thrust of back-arc ophiolitic sequence onto the old arc units mentioned above (Triantafyllou et al., 2016). This scheme is likely applicable to arc-related complexes from the Bou Azzer inlier with thrusting back-arc Ait Ahmane ophiolite onto the Bougmane-Tazigzaout and Bou Azzer Mine gneissic arc complexes to the south (Fig. 12B). Therefore, the D1 event is interpreted as resulting from a major shortening event (D'Lemos et al., 2006; Triantafyllou et al., 2016) that occurred in an intra-oceanic setting. From Tachakoucht and Bougmane cases study, we know that the D1 event involved significant crustal thickening through the stacking of crustal units belonging to the IGN1-related intra-oceanic arc system (Fig. 12B). Interestingly, shortening tectonics is relatively rare in modern IOAS. Most of intra-oceanic subduction zones are rather characterized by extensive stresses within the overriding crust ( $c f$. Marianna, Tonga, Kermadec arc systems; Lallemand et al., 2008) or by a stable subduction regime (cf. Aleutian arc system; Heuret and Lallemand, 2005). This can be explained because none of these IOAS implies in its geodynamic context a sufficient strain accumulation in the overriding crust to result in 
A Building of a primary oceanic arc (\& back-arc) (IGN1)
760-740 Ma

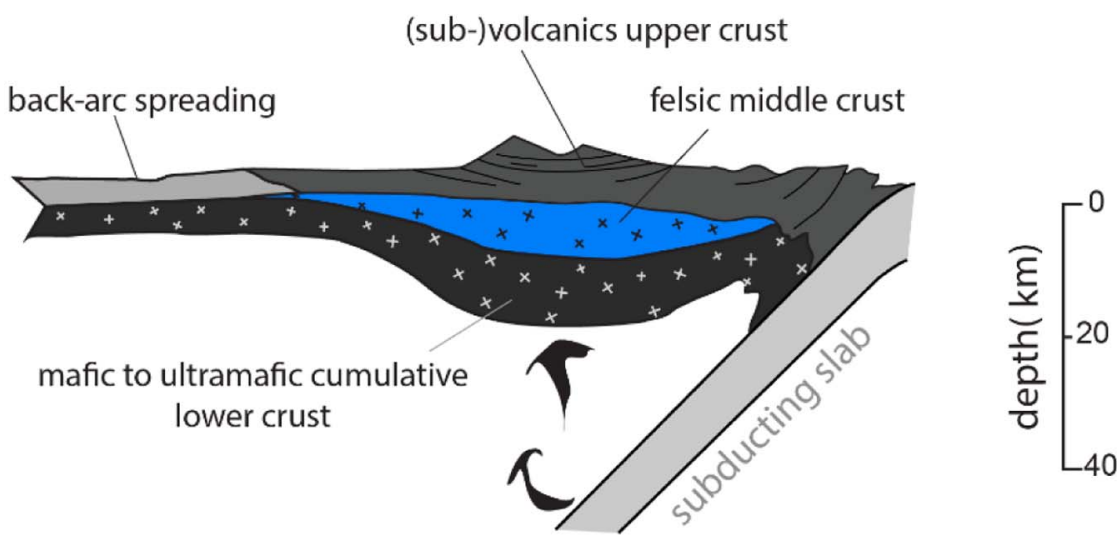

\section{B Shortening (D1) and magmatic driven arc thickening (IGN2-MET2) \\ 710-690 Ma}

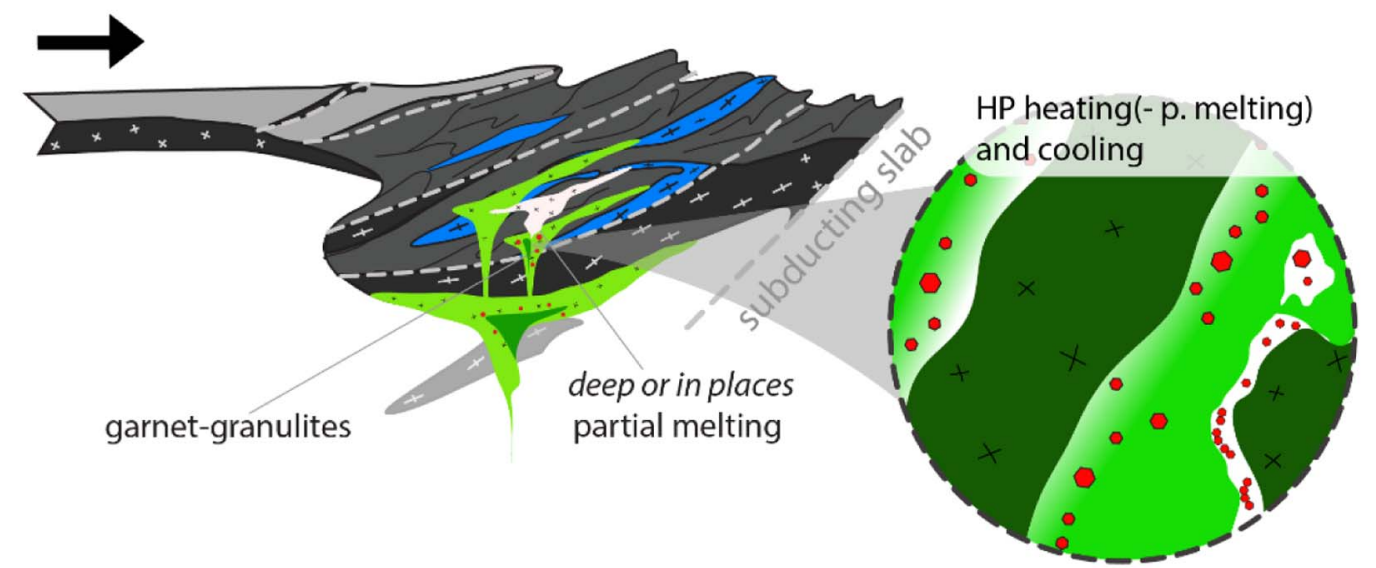

C Last oceanic arc magmatic pulse (IGN3)

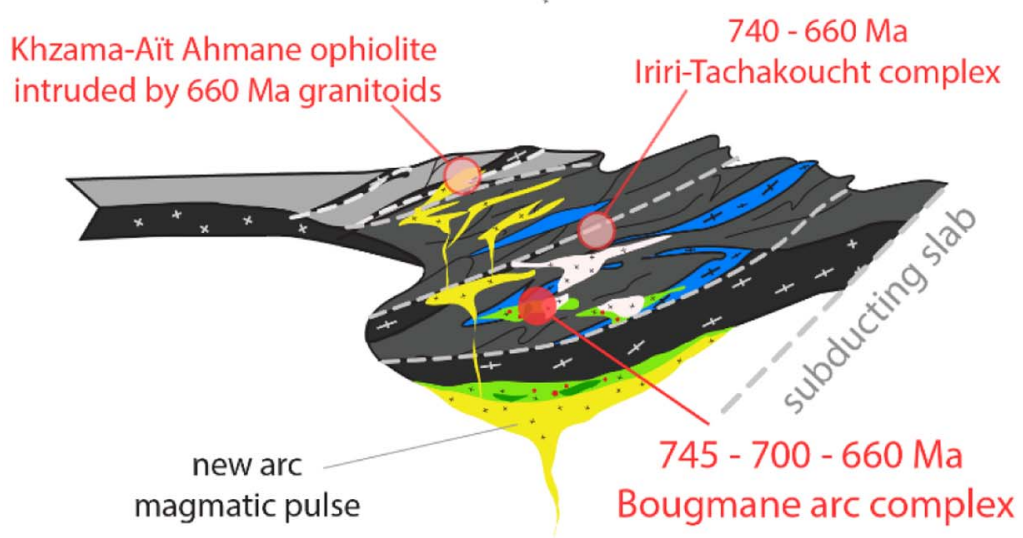

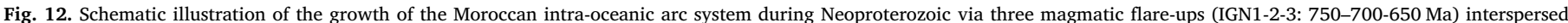

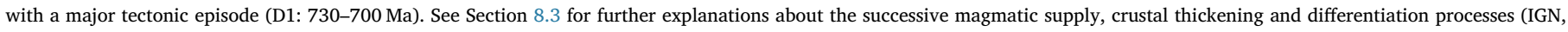
igneous event; D and MET, tectonic and metamorphic event respectively; $c f$. Fig. 2 for lithological legend). 
significant deformation of the arc itself (but rather in the back- or forearc region; e.g., Hasegawa et al., 2005; Arcay et al., 2008; Boutelier and Chemenda, 2011). Similarly, analogue and numerical geodynamic models showed that shortening tectonics in IOAS are generally localized in the weakest crustal portions of the IOAS (i.e. fore- and/or backarc settings; Boutelier et al., 2003; Heuret et al., 2007; Gerya, 2011; Vogt and Gerya, 2014). However, other authors (e.g., Sizova et al., 2010; Tetreault and Buiter, 2012; Baitsch-Ghirardello et al., 2014) proposed that in certain peculiar geodynamic conditions (slab anchoring, buoyant arc accretion, trench migration, etc.) the arc area itself can be deformed during shortening. Therefore, we propose that, between 730 and $700 \mathrm{Ma}$, the Moroccan oceanic arc underwent a major shortening tectonic regime likely related to a modification in the dynamic of subduction.

The 710-690 Ma igneous event (IGN2; Fig. 12B) was recognized for the first time by D'Lemos et al. (2006) in the Tazigzaout complex. This event has not been discovered in the Sirwa window yet. In the Bou Azzer window and through Bougmane records in particular, we showed that IGN2 event is marked by the emplacement of succesive igneous units made of hydrous oceanic arc magmas, garnet-granulitic reactions and felsic melts produced by partial melting deep in the crust. These arguments show that the Moroccan oceanic arc had reached a significant maturation stage with minimum $30-35 \mathrm{~km}$ crustal thickness before $\sim 700 \mathrm{Ma}$ (Fig. $12 \mathrm{~b}$ ). Modern oceanic arcs with a mature architecture (i.e. thickened crust and heterogeneous crust composition) result from a longer magmatic activity (see the Aleutian oceanic arc; Holbrook et al., 1999; Jicha et al., 2006; Whattam et al., 2008). Hence, their mature structure is thought to be mainly driven by magma accumulation at different levels of the crust and intra-crustal differentiation processes. Concerning the Moroccan paleo-arc, arc growth mechanisms probably combine: (i) magmatic by accumulation of igneous products from IGN1 and IGN2 episodes but also (ii) most likely tectonic via D1 shortening and stacking event.

The 660-640 Ma igneous arc event (IGN3; Fig. 12C) is marked by the emplacement of several dioritic plutons in the Bou Azzer window within the northern ophiolitic unit and the northern part of Tazigzaout and Oumlil arc complexes (Inglis et al., 2005; El Hadi et al., 2010; Walsh et al., 2012; Fig. 1b). These igneous units have geochemical characteristics of oceanic arc magmas (Mrini, 1993; Beraaouz et al., 2004). The thermal impact of this igneous event has been recorded in Bougmane garnet-rutile bearing mafic rocks as documented by rutile U$\mathrm{Pb}$ age of $658 \pm 7 \mathrm{Ma}$. In the Sirwa window, this third igneous event is also marked by the emplacement of hornblendite stocks which induced remelting of older arc units, namely the Tachakoucht gneisses, and leaded to the production of leucogranitic melts dated around 650-640 Ma (Triantafyllou et al., 2016). These leucogranites from Sirwa and the dioritic plutons from Bou Azzer windows both intrude their respective back-arc ophiolitic sequences (El Hadi et al., 2010; Triantafyllou et al., 2016) suggesting that the 'arc-backarc pile' was already stacked before the 650 Ma magmatic event (Fig. 12C) or alternatively, that the magmatic centre migrates backwards to the arc sensu stricto (Stern, 2010).

Both IGN2 and IGN3 igneous events are characterized by an oceanic arc signature in the Pan-African belt suggesting that the old radiogenic crust from the WAC was not implicated in their magmagenetic processes and that arc obduction onto the WAC was more likely achieved around $630 \mathrm{Ma}$ as suggested by Gasquet et al. $(2005,2008)$ based on collisional tectonics and syn- to post-collisional magmatism. Concerning the Neoproterozoic Moroccan arc, we suggest that its growth continued through IGN2 and IGN3 events as an accreted portion of the oceanic crust but still in an intra-oceanic setting. This 120 Ma geodynamic evolution is comparable to the Mesozoic Kohistan arc which grew in an intra-oceanic domain during $~ 100$ Ma prior to its obduction onto the Eurasian plate (Schaltegger et al., 2003; Burg et al., 2005; Bouilhol et al., 2011, 2013; Bosch et al., 2011). These authors showed that the Kohistan arc has been affected amongst others by several phases of magmatic growth, episode of intra-arc splitting/rifting, and an early accretion stage of the arc against the Indian margin (see Burg (2011) for a comprehensive review). The latter occurred around 65-55 Ma after which the intra-oceanic arc activity continued - generating igneous products that intruded previous arc crust - until the true obduction of the arc and the closure and suturing of the oceanic domains $\sim 50 \mathrm{Ma}$ later.

\section{Concluding remarks}

- We showed that the Bougmane arc complex traces the growth of an intra-oceanic arc setting during the Cryogenian. Its magmatic activity spans during $120 \mathrm{Ma}$ via three igneous oceanic arc flare-ups (IGN1-2-3: 750-700-650 Ma respectively) which have been interspersed with a major tectonic episode (D1: 730-700 Ma).

- This study attests that the Moroccan arc reached a thick and mature crustal structure before the $700 \mathrm{Ma}$ event. Indeed, the latter led to HP garnet-granulitic reactions (sub- to supra-solidus reactions) as well as the production of felsic magmas with adakitic signature.

- The thickening process is thought to be driven by magma accumulation at different levels of the crust - as generally proposed for Phanerozoic paleo-arcs and modern IOAS - but also by shortening tectonic regime and intra-arc stacking deformation (D1).

- Further tests by numerical geodynamic modelling are needed to show if intra-oceanic shortening can lead to stacking and important thickening of the oceanic crust. Such an approach may help explaining why active arc systems are rarely affected by tectonic accretion, shortening and stacking regime.

- Studying records from other Precambrian and Phanerozoic paleoarcs is crucial to highlight, characterize and explain differences between IOAS geodynamics through geological times.

\section{Acknowledgments}

We would like to thank the Belgian FRS - FNRS for its financial support (AT is a FRIA-FNRS fellow). We also want to thank Prof. Mohammed Boutaleb for its great contribution on the field and his logistical support as well as the Faculty of Sciences at the Université Chouaiib Doukkali (El Jadida, Morocco). This study has been partially funded by an INSU-SYSTER project. We thank Th. Zack for providing rutile SRM; Ch. Douchet for her help during samples preparation in the blank lab; S. Buck, S. Ignatieva and M. Harrild for their attentive proofing. We also thank two anonymous reviewers for their constructive comments as well as Dr. Kamal Ali and Pr. G. Zhao for their editorial handling.

\section{Appendix A. Analytical procedures}

\section{A.1. EPMA analyses conditions}

Mineral major elements analyses were conducted at the University of Mons using a Cameca SX50 electron microprobe (EPMA) equipped with a SamX acquisition system. Beam conditions were $15 \mathrm{kV}$ accelerating voltage and $20 \mathrm{nA}$ beam current and $\sim 1 \mu \mathrm{m}$ spot size. Counting times were set to $10 \mathrm{~s}$ for peaks and $10 \mathrm{~s}$ for backgrounds. The standards used were natural wollastonite ( $\mathrm{Si} \alpha \alpha$; $\mathrm{Ca} \mathrm{k} \alpha$ ), synthetic periclase (Mg

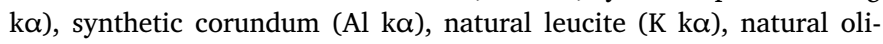

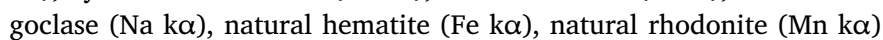
and natural chromite $(\mathrm{Cr} \mathrm{k} \alpha)$. The detection limit is around $0.1 \mathrm{wt} \%$. EPMA data can be found in Tables B2-B4.

\section{A.2. Cathodoluminescence}

Zircon crystals were identified and characterized under coldcathode optical cathodoluminescence (CL) at the University of Mons using a Cambridge Image Technology model 8200 Mk5 system. 
Operating conditions were $15 \mathrm{kV}$ accelerating voltage, $500 \mu \mathrm{A}$ beam current and a $c a .30 \mathrm{~mm}^{2}$ defocused beam.

\section{A.3. LA-ICP-MS analytical procedures}

\section{A.3.1. In situ trace elements analyses}

Rutile trace elements. Rutile is a very common accessory phase in Bougmane mafic and ultramafic lithologies. We performed in situ analyses of trace elements in the same set of rutile that are investigated for $\mathrm{U}-\mathrm{Pb}$ dating (samples of garnet-bearing hornblende-gabbro: BO10B and of hornblendite: ASL22B). Trace element analyses were carried out with a single collector double-focusing sector field Element XR (eXtended Range) ICP-mass spectrometer coupled with a Geolas (Microlas) automated platform composed of an ArF $193 \mathrm{~nm}$ Compex 102 laser from LambdaPhysik (LA-SF-ICP-MS, at Montpellier II University). Each sample analysis lasts $3^{\prime \prime}$ of signal acquisition, with $1^{\prime} 45^{\prime \prime}$ devoting for the gas blank (laser disabled) and $11^{\prime} 15^{\prime \prime}$ for the analysis during rutile ablation (laser enabled). The laser was fired at a frequency of $6 \mathrm{~Hz}$ in static mode. Each samples were pre-ablated with a $77 \mu \mathrm{m}$ spot size to clean surface impurities and with a spot of $52 \mu \mathrm{m}$ for the analysis. ${ }^{49} \mathrm{Ti}$ has been measured in each analysis in order to use it as an internal standard; $\mathrm{TiO}_{2}$ content is set to 99.3 and $99.8 \mathrm{wt} \%$ for BO10B and ASL $22 \mathrm{~B}$ respectively (depending on the mean of $\mathrm{TiO}_{2}$ contents of rutile measured by EPMA for each sample). Bulk analyses were calibrated against the NIST standard reference materials (SRM) 610 glass. Reference values were gathered from GeoReM database (http:// georem.mpch-mainz.gwdg.de/; Jochum et al., 2005). Accuracy of the data was also tested and validated by analysing as 'known unknown' of the R10b rutile SRM (Luvizotto and Zack, 2009). Data were reduced and element concentrations calculated using the 'GLITTER' software (Griffin et al., 2008; Table B6).

Zircon trace elements. We performed in situ analyses of trace elements in the same set of zircons that was investigated for U-Pb dating (sample of garnet-bearing leucosome: ASL17C). Trace element analyses were carried out with the same LA-ICP-MS apparatus and the same analytical procedure described for rutile trace element analyses. Si content has been used as an internal standard and defined by stoichiometry (zircon $\sim 31.5 \mathrm{wt} \% \mathrm{SiO}_{2}$ ). Bulk analyses were calibrated against the NIST standard reference materials (SRM) 610 glass. Reference values as for rutile analyses. Accuracy of the data was also tested and validated by analysing as 'known unknown' of the zircon 91500 SRM (Wiedenbeck et al., 1995). Data were reduced and element concentrations calculated using the 'GLITTER' software (Griffin et al., 2008; Table B5).

\section{A.3.2. $U$-Pb dating}

$\mathrm{U}-\mathrm{Pb}$ dating were carried out for constitutive zircons (for garnet-rich leucosome: ASL17C; Table B7) and rutiles (for garnet-bearing hornblende-gabbro: BO10B; Table B8 and for hornblendite: ASL22B; Table B9) with the same LA-SF-ICP-MS instrument using similar analytical conditions. Laser ablation (LA-) ICP-MS analyses have been performed at the Montpellier II University using a single collector double-focusing sector field Element XR (eXtended Range) ICP-MS, coupled with a Geolas (Microlas) automated platform composed of an $\operatorname{ArF} 193 \mathrm{~nm}$ Compex 102 laser from LambdaPhysik. Each zircon and rutile crystal was analysed devoting $15 \mathrm{~s}$ for the blank (laser disabled), and $50 \mathrm{~s}$ for signal acquisition during mineral ablation (laser enabled). Before each analysis, the targeted zone is cleaned with 10 laser pulses with a spot size twice larger than the one used for the isotopic analysis $(52 \mu \mathrm{m}$ for zircons and $71 \mu \mathrm{m}$ for rutiles at $\sim 0.1 \mu \mathrm{m}$ ablation per laser pulse).

For zircons. The laser was fired at a frequency of $3 \mathrm{~Hz}$ in static mode with a spot size of $26 \mu \mathrm{m}$. Zircon SRM 91500 was used as an external standard (Wiedenbeck et al., 1995) and every five unknowns' analyses were followed by two analyses of 91,500 zircon standard.

For rutiles. The laser was fired at a frequency of $4 \mathrm{~Hz}$ in static mode with a spot size of $51 \mu \mathrm{m}$. Rutile SRM R10b was used as an external standard (Zack et al., 2011; Luvizotto and Zack, 2009) and every five unknowns' analyses were followed by two analyses of R10 rutile standard.

$\mathrm{U}-\mathrm{Th}-\mathrm{Pb}$ isotopic data (in counts per second) were then manually reduced using the GLITTER software (Griffin et al., 2008) by carefully selecting which ranges of time to integrate for instrument/gas blank and analysis calculation (avoiding inclusions or fractures effects). We discarded spectra that show significant irregularities of the isotopic ratios $v s$ time, suggesting that the analysis spot met a heterogeneous area of the analysed mineral (i.e. core - rim boundary, inclusions). Each uniform spectrum provides for each spot, $\mathrm{U}$-Pb-Th isotopic ratios usable for age determination. Isotopic ratios for zircons are directly imported in a spreadsheet and $\mathrm{U}-\mathrm{Pb}$ age are calculated using Isoplot software (Ludwig, 2003). Rutile isotopic data must be firstly corrected from common lead $\left(P b_{c}\right)$. Initial common lead correction was applied treating measured ${ }^{208} \mathrm{~Pb}$ as initial common lead. This is possible due to very low Th concentrations and low $\mathrm{Th} / \mathrm{U}$ ratios (lower than 0.004 and 0.018 respectively) in all analysed rutiles, ensuring no ${ }^{208} \mathrm{~Pb}$ is radiogenic. The isotope ratios for the common $\mathrm{Pb}$ were calculated using the evolution model for terrestrial Pb by Stacey and Kramers (1975; propagating an uncertainty of $2 \%$ ) and ${ }^{208} \mathrm{~Pb}$-corrected isotopic ratios were calculated using Eqs. (1) and (2) found in Zack et al. (2011; Tables B8 and B9).

\section{A.4. Whole rock analysis}

Major elements have been determined on bulk samples either by Xray Fluorescence (XRF) at the ICP-MS Laboratory of Central Analytical Facilities (CAF; Stellenbosch University, South Africa) and by ICP-AES at the SARM (CRPG-CNRS, Nancy, France). Rock powders have been mixed with lithium tetraborate and heated at $1000^{\circ} \mathrm{C}$ during two hours. For XRF, glass beads were made in a platinum mold while for ICP-AES, the molten mixture has been diluted in $2 \% \mathrm{HNO}_{3}$. Calibration was made using a set of natural and artificial reference materials. Detailed methods and accuracies can be found in Carignan et al. (2001) for the SARM certified procedure.

Trace elements on bulk samples have been analysed at the ICP-MS laboratory of the University of Montpellier II using a quadrupole ICPMS (Agilent $7700 \times$ ). Rock powders have been dissolved by two successive acid attack: adding a HF/HClO4 mixture $(3 / 1 \mathrm{ml}$ and $1 / 1 \mathrm{ml}$ successively) to the powder in a Teflon recipient, heating it for $48 \mathrm{~h}$ at $120^{\circ} \mathrm{C}$ and evaporating. The dissolved residues have been diluted in $\mathrm{HNO}_{3}$ suprapur $65 \%$ and $\mathrm{H}_{2} \mathrm{O}$ milliQ. Two internal standard are added to each solution to correct instrument derivation (indium and bismuth at $10 \mathrm{ppb}$ ). Two chemical blanks and two SRM powders (BE-N and UBN; Jochum et al., 2005) have been prepared and analysed with the same analytical procedure as for samples. External standards were analysed to validate the reproducibility and quality of analyses and unknowns' analyses were calibrated using artificial home-made calibration solution (see Godard et al. (2000) for more details about detection limits and calibration procedure). Geochemical data can be found in Table B1.

\section{A.5. Nd isotope geochemical analyses}

Rock powders were dissolved in $\mathrm{HF}-\mathrm{HNO}_{3}$ mixture (3:1) and Nd was isolated by ion-exchange chromatography following the method described by Pin et al. (1994). Isotopic ratio measurements were carried on a Finnigan Mat 261 thermal ionization mass spectrometer (TIMS) at GET laboratory (Toulouse, France). Nd was loaded on a Re filament. Each analysis consists of at least 120 repeated measurements of the isotopic ratios. Analyses of La Jolla standard are clustered and consistent with published values.

\section{Appendix B. Supplementary material}

Supplementary data associated with this article can be found, in the 
online version, at http://dx.doi.org/10.1016/j.precamres.2017.10.022. These data include Google maps of the most important areas described in this article.

\section{References}

Admou, A., Fekkak, A., Razin, Ph., Egal, E., Youbi, N., Soulaimani, A., Blein, O., Baudin, T., Chèvremont, Ph., 2013. Carte géologique au 1/50 000), feuille Aït Ahmane. Notes et Mémoires du Service Géologique du Maroc 533, 154.

Ahmed, A.H., Arai, S., Abdel-Aziz, Y.M., Rahimi, A., 2005. Spinel composition as a petrogenetic indicator of the mantle section in the Neoproterozoic Bou Azzer ophiolite, Anti-Atlas, Morocco. Precamb. Res. 138 (3), 225-234.

Allegre, C.J., Minster, J.F., 1978. Quantitative models of trace element behavior in magmatic processes. Earth Planet. Sci. Lett. 38 (1), 1-25.

Alonso-Perez, R., Müntener, O., Ulmer, P., 2009. Igneous garnet and amphibole fractionation in the roots of island arcs: experimental constraints on andesitic liquids. Contrib. Miner. Petrol. 157 (4), 541-558.

Anderson, J.L., Smith, D.R., 1995. The effects of temperature and $\mathrm{fO}_{2}$ on the $\mathrm{Al}$-inhornblende barometer. Am. Miner. 80 (5-6), 549-559.

Annen, C., Blundy, J.D., Sparks, R.S.J., 2006. The genesis of intermediate and silicic magmas in deep crustal hot zones. J. Petrol. 47 (3), 505-539.

Arcay, D., Lallemand, S., Doin, M.P., 2008. Back-arc strain in subduction zones: statistical observations versus numerical modeling. Geochem. Geophys. Geosyst. 9 (5).

Baby, P., Rochat, P., Mascle, G., Hérail, G., 1997. Neogene shortening contribution to crustal thickening in the back arc of the Central Andes. Geology 25 (10), 883-886.

Baitsch-Ghirardello, B., Gerya, T.V., Burg, J.P., 2014. Geodynamic regimes of intraoceanic subduction: Implications for arc extension vs. shortening processes. Gondwana Res. 25 (2), 546-560.

Beate, B., Monzier, M., Spikings, R., Cotten, J., Silva, J., Bourdon, E., Eissen, J.P., 2001. Mio-Pliocene adakite generation related to flat subduction in southern Ecuador: the Quimsacocha volcanic center. Earth Planet. Sci. Lett. 192 (4), 561-570.

Behn, M.D., Kelemen, P.B., 2006. Stability of arc lower crust: insights from the Talkeetna arc section, south central Alaska, and the seismic structure of modern arcs. J. Geophys. Res.: Solid Earth 111 (B11).

Beraaouz, E.H., Ikenne, M., Mortaji, A., Madi, A., Lahmam, M., Gasquet, D., 2004. Neoproterozoic granitoids associated with the Bou-Azzer ophiolitic melange (AntiAtlas, Morocco): evidence of adakitic magmatism in an arc segment at the NW edge of the West-African craton. J. Afr. Earth Sc. 39 (3), 285-293.

Berger, J., Caby, R., Liégeois, J.P., Mercier, J.C.C., Demaiffe, D., 2011. Deep inside a neoproterozoic intra-oceanic arc: growth, differentiation and exhumation of the Amalaoulaou complex (Gourma, Mali). Contrib. Miner. Petrol. 162 (4), 773-796.

Berger, J., Caby, R., Liégeois, J.P., Mercier, J.C.C., Demaiffe, D., 2009. Dehydration, melting and related garnet growth in the deep root of the Amalaoulaou Neoproterozoic magmatic arc (Gourma, NE Mali). Geol. Mag. 146 (02), 173-186.

Berly, T.J., Hermann, J., Arculus, R.J., Lapierre, H., 2006. Supra-subduction zone pyroxenites from San Jorge and Santa Isabel (Solomon Islands). J. Petrol. 47 (8), 1531-1555.

Blein, O., Baudin, T., Chevremont, P., Soulaimani, A., Admou, H., Gasquet, P., Cocherie, A., Egal, E., Youbi. N., Razin, P., Gombert, P., Bouabdelli, M., 2014. Geochronological constraints on the polycyclic magmatism in the Bou Azzer-El Graara inlier (Central Anti-Atlas Morocco). J. Afr. Earth Sci., 99, 287-306.

Blundy, J.D., Holland, T.J., 1990. Calcic amphibole equilibria and a new amphiboleplagioclase geothermometer. Contrib. Miner. Petrol. 104 (2), 208-224.

Bodinier, J.L., Dupuy, C., Dostal, J., 1984. Geochemistry of Precambrian ophiolites from Bou Azzer, Morocco. Contrib. Mineral. Petrol. 87 (1), 43-50.

Bosch, D., Garrido, C.J., Bruguier, O., Dhuime, B., Bodinier, J.L., Padròn-Navarta, J.A., Galland, B., 2011. Building an island-arc crustal section: time constraints from a LAICP-MS zircon study. Earth Planet. Sci. Lett. 309 (3), 268-279.

Bouilhol, P., Jagoutz, O., Hanchar, J.M., Dudas, F.O., 2013. Dating the India-Eurasia collision through arc magmatic records. Earth Planet. Sci. Lett. 366, 163-175.

Bouilhol, P., Schaltegger, U., Chiaradia, M., Ovtcharova, M., Stracke, A., Burg, J.P., Dawood, H., 2011. Timing of juvenile arc crust formation and evolution in the Sapat Complex (Kohistan-Pakistan). Chem. Geol. 280 (3), 243-256.

Bousquet, R., El Mamoun, R., Saddiqi, O., Goffé, B., Möller, A., Madi, A., 2008. Mélanges and ophiolites during the Pan-African orogeny: the case of the Bou-Azzer ophiolite suite (Morocco). Geol. Soc., Lond., Special Publ. 297 (1), 233-247.

Boutelier, D., Chemenda, A., 2011. Physical modeling of arc-continent collision: a review of 2D, 3D, purely mechanical and thermo-mechanical experimental models. In: Brown, D., Ryan, P.D. (Eds.), Arc Continent Collisions, Frontiers in Earth Science. Springer, Berlin Heidelberg, pp. 121-145.

Boutelier, D., Chemenda, A., Burg, J.P., 2003. Subduction versus accretion of intraoceanic volcanic arcs: insight from thermo-mechanical analogue experiments. Earth Planet. Sci. Lett. 212 (1), 31-45.

Burg, J.P., Bodinier, J.L., Chaudhry, S., Hussain, S., Dawood, H., 1998. Infra-arc mantlecrust transition and intra-arc mantle diapirs in the Kohistan Complex (Pakistani Himalaya): petro-structural evidence. Terra Nova-Oxford 10, 74-80.

Burg, J.P., 2011. The Asia-Kohistan-India collision: review and discussion. In: Brown, D., Ryan, P.D. (Eds.), Arc Continent Collisions, Frontiers in Earth Science. Springer, Berlin Heidelberg, pp. 121-145.

Burg, J.P., Arbaret, L., Chaudhry, N.M., Dawood, H., Hussain, S., Zeilinger, G., 2005. Shear strain localization from the upper mantle to the middle crust of the Kohistan Arc (Pakistan). Geol. Soc., Lond., Special Publ. 245 (1), 25-38.

Caby, R., Andreopoulos-Renaud, U., Pin, C., 1989. Late Proterozoic arc-continent and continent-continent collision in the Pan-African Trans-Saharan Belt of Mali. Can.
Earth Sci. 26 (6), 1136-1146.

Caby, R., 2003. Terrane assembly and geodynamic evolution of central-western Hoggar: a synthesis. J. Afr. Earth Sci. 37 (3), 133-159.

Caddick, M.J., Konopásek, J., Thompson, A.B., 2010. Preservation of garnet growth zoning and the duration of prograde metamorphism. J. Petrol. 51 (11), 2327-2347.

Calvert, A.J., Klemperer, S.L., Takahashi, N., Kerr, B.C., 2008. Three-dimensional crustal structure of the Mariana island arc from seismic tomography. J. Geophys. Res.: Solid Earth 113 (B1).

Calvert, A.J., 2011. The seismic structure of island arc crust. In: Brown, D., Ryan, P.D. (Eds.), Arc Continent Collisions, Frontiers in Earth Science. Springer, Berlin Heidelberg, pp. 121-145.

Carignan, J., Hild, P., Mevelle, G., Morel, J., Yeghicheyan, D., 2001. Routine analyses of trace elements in geological samples using flow injection and low pressure on-line liquid chromatography coupled to ICP-MS: a study of geochemical reference materials BR, DR-N, UB-N, AN-G and GH. Geostand. Newslett. 25 (2-3), 187-198.

Chappell, B.W., White, A.J.R., 2001. Two contrasting granite types: 25 years later. Aust. J. Earth Sci. 48 (4), 489-499.

Cherniak, D.J., 2000. Pb diffusion in rutile. Contrib. Miner. Petrol. 139 (2), 198-207.

Choubert, G., 1963. Service des mines et de la carte géologique, Carte géologique du flanc sud de l'Anti-Atlas Occidental et des plaines du Draah, Service géologique du Maroc. Morocco.

Condie, K.C., 2005. TTGs and adakites: are they both slab melts? Lithos 80 (1), 33-44.

Condie, K.C., 1997. Contrasting sources for upper and lower continental crust: the greenstone connection. J. Geol. 105 (6), 729-736.

Connolly, J.A., 2005. Computation of phase equilibria by linear programming: a tool for geodynamic modeling and its application to subduction zone decarbonation. Earth Planet. Sci. Lett. 236 (1), 524-541.

Connolly, J.A.D., 2009. The geodynamic equation of state: what and how. Geochem. Geophys. Geosyst. 10 (10).

Corfu, F., Hanchar, J.M., Hoskin, P.W., Kinny, P., 2003. Atlas of zircon textures. Rev. Mineral. Geochem. 53 (1), 469-500.

D'Lemos, R.S., Inglis, J.D., Samson, S.D., 2006. A newly discovered orogenic event in Morocco: Neoproterozoic ages for supposed Eburnean basement of the Bou Azzer inlier, Anti-Atlas Mountains. Precamb. Res. 147 (1), 65-78.

Dale, J., Holland, T., Powell, R., 2000. Hornblende-garnet-plagioclase thermobarometry: a natural assemblage calibration of the thermodynamics of hornblende. Contrib. Miner. Petrol. 140 (3), 353-362.

De Araujo, C.E.G., Rubatto, D., Hermann, J., Cordani, U.G., Caby, R., Basei, M.A., 2014 Ediacaran 2,500-km-long synchronous deep continental subduction in the West Gondwana Orogen. Nat. Commun. 5, 5198.

DeBari, S.M., Coleman, R.G., 1989. Examination of the deep levels of an island arc: evidence from the Tonsina Ultramafic-Mafic Assemblage, Tonsina, Alaska. J. Geophys. Res.: Solid Earth 94 (B4), 4373-4391.

DeBari, S.M., Greene, A.R., 2011. Vertical stratification of composition, density, and inferred magmatic processes in exposed arc crustal sections. In: Brown, D., Ryan, P.D. (Eds.), Arc Continent Collisions, Frontiers in Earth Science. Springer, Berlin Heidelberg, pp. 121-145.

Debret, B., Nicollet, C., Andreani, M., Schwartz, S., Godard, M., 2013. Three steps of serpentinization in an eclogitized oceanic serpentinization front (Lanzo MassifWestern Alps). J. Metamorph. Geol. 31 (2), 165-186.

DeCelles, P.G., Ducea, M.N., Kapp, P., Zandt, G., 2009. Cyclicity in Cordilleran orogenic systems. Nat. Geosci. 2 (4), 251-257.

Defant, M.J., Drummond, M.S., 1990. Derivation of some modern arc magmas by melting of young subducted lithosphere. Nature 347 (6294), 662-665.

DePaolo, D.J., Wasserburg, G.J., 1977. The sources of island arcs as indicated by Nd and Sr isotopic studies. Geophys. Res. Lett. 4 (10), 465-468.

Dhuime, B., Bosch, D., Bodinier, J.L., Garrido, C.J., Bruguier, O., Hussain, S.S., Dawood, H., 2007. Multistage evolution of the Jijal ultramafic-mafic complex (Kohistan, N Pakistan): implications for building the roots of island arcs. Earth Planet. Sci. Lett. 261 (1), 179-200.

Dhuime, B., Bosch, D., Garrido, C.J., Bodinier, J.L., Bruguier, O., Hussain, S.S., Dawood, H., 2009. Geochemical architecture of the lower-to middle-crustal section of a paleoisland arc (Kohistan Complex, Jijal-Kamila area, northern Pakistan): implications for the evolution of an oceanic subduction zone. J. Petrol., egp010.

Dimalanta, C., Taira, A., Yumul, G.P., Tokuyama, H., Mochizuki, K., 2002. New rates of western Pacific island arc magmatism from seismic and gravity data. Earth Planet. Sci. Lett. 202 (1), 105-115.

Dostal, J., Dupuy, C., Caby, R., 1994. Geochemistry of the Neoproterozoic Tilemsi belt of Iforas (Mali, Sahara): a crustal section of an oceanic island arc. Precambr. Res. 65 (1-4), 55-69.

Dunn, T., Sen, C., 1994. Mineral/matrix partition coefficients for orthopyroxene, plagioclase, and olivine in basaltic to andesitic systems: a combined analytical and experimental study. Geochim. Cosmochim. Acta 58 (2), 717-733.

El Hadi, H., Simancas, J.F., Martínez-Poyatos, D., Azor, A., Tahiri, A., Montero, P., Fanning, C.M., Bea, F., González-Lodeiro, F., 2010. Structural and geochronological constraints on the evolution of the Bou Azzer Neoproterozoic ophiolite (Anti-Atlas, Morocco). Precambr. Res. 182 (1), 1-14.

El Hadi, H., Tahiri, A., Simancas, J.F., González-Lodeiro, F., Azor, A., Martínez-Poyatos, D., 2011. Geoheritage in Morocco: the Neoproterozoic Ophiolite of Bou Azzer (Central Anti-Atlas). Geoheritage 3 (2), 89-96.

Ellis, D.J., Thompson, A.B., 1986. Subsolidus and partial melting reactions in the quartzexcess $\mathrm{CaO}+\mathrm{MgO}+\mathrm{Al}_{2} \mathrm{O}_{3}+\mathrm{SiO}_{2}+\mathrm{H} 2 \mathrm{O}$ system under water-excess and waterdeficient conditions to $10 \mathrm{~kb}$ : some implications for the origin of peraluminous melts from mafic rocks. J. Petrol. 27 (1), 91-121.

Ennih, N., Liégeois, J.P., 2008. The boundaries of the West African craton, with special reference to the basement of the Moroccan metacratonic Anti-Atlas belt. Geol. Soc., 
Lond., Special Publ. 297 (1), 1-17.

Ernst, W.G., Liu, J., 1998. Experimental phase-equilibrium study of Al-and Ti-contents of calcic amphibole in MORB - a semiquantitative thermobarometer. Am. Miner. 83 (9-10), 952-969.

Errami, E., Bonin, B., Laduron, D., Lasri, L., 2009. Petrology and geodynamic significance of the post-collisional Pan-African magmatism in the Eastern Saghro area (Anti-Atlas, Morocco). J. Afr. Earth Sc. 55 (1), 105-124.

Ewing, T.A., Hermann, J., Rubatto, D., 2013. The robustness of the Zr-in-rutile and Ti-inzircon thermometers during high-temperature metamorphism (Ivrea-Verbano Zone, northern Italy). Contrib. Miner. Petrol. 165 (4), 757-779.

Féménias, O., Mercier, J.C.C., Nkono, C., Diot, H., Berza, T., Tatu, M., Demaiffe, D., 2006. Calcic amphibole growth and compositions in calc-alkaline magmas: Evidence from the Motru Dike Swarm (Southern Carpathians, Romania). Am. Miner. 91 (1), 73-81.

Frost, B.R., Barnes, C.G., Collins, W.J., Arculus, R.J., Ellis, D.J., Frost, C.D., 2001. A geochemical classification for granitic rocks. J. Petrol. 42 (11), 2033-2048.

Garrido, C.J., Bodinier, J.L., Burg, J.P., Zeilinger, G., Hussain, S.S., Dawood, H., Chaudhry and Gervilla, F., 2006. Petrogenesis of mafic garnet granulite in the lower crust of the Kohistan paleo-arc complex (Northern Pakistan): implications for intra-crustal differentiation of island arcs and generation of continental crust. J. Petrol. 47 (10), 1873-1914.

Garrido, C.J., Bodinier, J.L., Dhuime, B., Bosch, D., Chanefo, I., Bruguier, O., Hussain, S.S., Dawood, H., Burg, J.P., 2007. Origin of the island arc Moho transition zone via melt-rock reaction and its implications for intracrustal differentiation of island arcs: evidence from the Jijal complex (Kohistan complex, northern Pakistan). Geology 35 (8), 683-686.

Gasquet, D., Levresse, G., Cheilletz, A., Azizi-Samir, M.R., Mouttaqi, A., 2005. Contribution to a geodynamic reconstruction of the Anti-Atlas (Morocco) during PanAfrican times with the emphasis on inversion tectonics and metallogenic activity at the Precambrian-Cambrian transition. Precambr. Res. 140 (3), 157-182.

Gasquet, D., Ennih, N., Liégeois, J.P., Soulaimani, A., Michard, A., 2008. The Pan-African belt. In: Michard, et al. (Eds.), Continental Evolution: The Geology of Morocco: Lecture Notes in Earth Sciences, vol. 116. Springer Verlag, Berlin, pp. 33-64.

Gazel, E., Hayes, J.L., Hoernle, K., Kelemen, P., Everson, E., Holbrook, W.S., Hauff, F., van den Bogaard, P., Vance, E., Chu, S., Carr, M., Yogodzinski, G., Calvert, A.J., 2015 Continental crust generated in oceanic arcs. Nat. Geosci. 8 (4), 321-327.

Gerya, T.V., Meilick, F.I., 2011. Geodynamic regimes of subduction under an active margin: effects of rheological weakening by fluids and melts. J. Metamorph. Geol. 29 (1), 7-31.

Gerya, T.V., 2011. Intra-oceanic subduction zones. In: Arc-Continent Collision. Springer, Berlin Heidelberg, pp. 23-51.

Godard, M., Jousselin, D., Bodinier, J.L., 2000. Relationships between geochemistry and structure beneath a palaeo-spreading centre: a study of the mantle section in the Oman ophiolite. Earth Planet. Sci. Lett. 180 (1), 133-148.

Gower, R.J., Simpson, C., 1992. Phase boundary mobility in naturally deformed, highgrade quartzofeldspathic rocks: evidence for diffusional creep. J. Struct. Geol. 14 (3), 301-313.

Green, E.C.R., White, R.W., Diener, J.F.A., Powell, R., Holland, T.J.B., Palin, R.M., 2016. Activity-composition relations for the calculation of partial melting equilibria for metabasic rocks. J. Metamorph. Geol. 34, 845-869.

Greene, A.R., DeBari, S.M., Kelemen, P.B., Blusztajn, J., Clift, P.D., 2006. A detailed geochemical study of island arc crust: the Talkeetna Arc section, south-central Alaska. J. Petrol. 47 (6), 1051-1093.

Griffin, W.L., Powell, W.J., Pearson, N.J., O'reilly, S.Y., 2008. GLITTER: data reduction software for laser ablation ICP-MS. Laser Ablation-ICP-MS in the earth sciences. Mineral. Assoc. Canada Short Course Series 40, 204-207.

Grove, T.L., Elkins-Tanton, L.T., Parman, S.W., Chatterjee, N., Müntener, O., Gaetani, G.A., 2003. Fractional crystallization and mantle-melting controls on calc-alkaline differentiation trends. Contrib. Miner. Petrol. 145 (5), 515-533.

Hamilton, W.B., 2007. Driving mechanism and 3-D circulation of plate tectonics. Geol Soc. Am. Spec. Pap. 433, 1-25.

Hasalová, P., Janoušek, V., Schulmann, K., Štípská, P., Erban, V., 2008. From orthogneiss to migmatite: geochemical assessment of the melt infiltration model in the Gföhl Unit (Moldanubian Zone, Bohemian Massif). Lithos 102 (3), 508-537.

Haschke, M., Günther, A., 2003. Balancing crustal thickening in arcs by tectonic vs. magmatic means. Geology 31 (11), 933-936.

Hasegawa, A., Nakajima, J., Umino, N., Miura, S., 2005. Deep structure of the northeastern Japan arc and its implications for crustal deformation and shallow seismic activity. Tectonophysics 403 (1), 59-75.

Hauri, E.H., Wagner, T.P., Grove, T.L., 1994. Experimental and natural partitioning of Th, $\mathrm{U}, \mathrm{Pb}$ and other trace elements between garnet, clinopyroxene and basaltic melts. Chem. Geol. 117 (1-4), 149-166.

Hefferan, K.P., Karson, J.A., Saquaque, A., 1992. Proterozoic collisional basins in a PanAfrican suture zone, Anti-Atlas Mountains, Morocco. Precambr. Res. 54 (2-4), 295-319.

Heuret, A., Lallemand, S., 2005. Plate motions, slab dynamics and back-arc deformation. Phys. Earth Planet. Inter. 149 (1), 31-51.

Heuret, A., Funiciello, F., Faccenna, C., Lallemand, S., 2007. Plate kinematics, slab shape and back-arc stress: a comparison between laboratory models and current subduction zones. Earth Planet. Sci. Lett. 256 (3), 473-483.

Hodel, F., Macouin, M., Triantafyllou, A., Carlut, J., Berger, J., Rousse, S., Trindade, R.I.F., 2017. Unusual massive magnetite veins and highly altered Cr-spinels as relics of a Cl-rich acidic hydrothermal event in Neoproterozoic serpentinites (Bou Azzer ophiolite, Anti-Atlas, Morocco). Precambr. Res. 300, 151-167.

Holbrook, W.S., Lizarralde, D., McGeary, S., Bangs, N., Diebold, J., 1999. Structure and composition of the Aleutian island arc and implications for continental crustal growth. Geology 27 (1), 31-34.
Haase, K.M., Lima, S., Krumm, S., Garbe-Schönberg, D., 2014. The magmatic evolution of young island arc crust observed in gabbroic to tonalitic xenoliths from Raoul Island, Kermadec Island Arc. Lithos 210, 199-208.

Holland, T.J.B., Powell, R., 1998. An internally consistent thermodynamic data set for phases of petrological interest. J. Metamor. Geol., 16(3), 309-343 (revised in 2002).

Holland, T., Blundy, J., 1994. Non-ideal interactions in calcic amphiboles and their bearing on amphibole-plagioclase thermometry. Contrib. Miner. Petrol. 116 (4) 433-447.

Inglis, J.D., D'Lemos, R.S., Samson, S.D., Admou, H., 2005. Geochronological constraints on late precambrian intrusion, metamorphism, and tectonism in the anti-atlas mountains. J. Geol. 113, 439-450.

Inglis, J.D., MacLean, J.S., Samson, S.D., D’Lemos, R.S., Admou, H., Hefferan, K., 2004. A precise U-Pb zircon age for the Bleïda granodiorite, Anti-Atlas, Morocco: implications for the timing of deformation and terrane assembly in the eastern Anti-Atlas. J. Afr. Earth Sc. 39 (3), 277-283.

Jagoutz, O., Behn, M.D., 2013. Foundering of lower island-arc crust as an explanation for the origin of the continental Moho. Nature 504 (7478), 131-134.

Jagoutz, O., Schmidt, M.W., Enggist, A., Burg, J.P., Hamid, D., Hussain, S., 2013. TTGtype plutonic rocks formed in a modern arc batholith by hydrous fractionation in the lower arc crust. Contrib. Miner. Petrol. 166 (4), 1099-1118.

Janák, M., Plašienka, D., Frey, M., Cosca, M., Schmidt, S., Lupták, B., Méres, Š., 2001. Cretaceous evolution of a metamorphic core complex, the Veporic unit, Western Carpathians (Slovakia): P-T conditions and in situ40Ar/39Ar UV laser probe dating of metapelites. J. Metamor. Geol. 19 (2), 197-216.

Jicha, B.R., Scholl, D.W., Singer, B.S., Yogodzinski, G.M., Kay, S.M., 2006. Revised age of Aleutian Island Arc formation implies high rate of magma production. Geology 34 (8), 661-664.

Jicha, B.R., Jagoutz, O., 2015. Magma production rates for intraoceanic arcs. Elements 11 (2), 105-111.

Jochum, K.P., Nohl, U., Herwig, K., Lammel, E., Stoll, B., Hofmann, A.W., 2005. GeoReM: a new geochemical database for reference materials and isotopic standards. Geostand. Geoanal. Res. 29 (3), 333-338.

Johannes, W., Holtz, F., 2012. Petrogenesis and Experimental Petrology of Granitic Rocks, vol. 22. Springer Science and Business Media.

Kelemen, P.B., Yogodzinski, G.M., Scholl, D.W., 2003. Along-strike variation in the Aleutian island arc: genesis of high $\mathrm{mg} \#$ andesite and implications for continental crust. Inside Subduct. Fact. 223-276.

Klein, M., Stosch, H.G., Seck, H.A., 1997. Partitioning of high field-strength and rareearth elements between amphibole and quartz-dioritic to tonalitic melts: an experimental study. Chem. Geol. 138 (3), 257-271.

Kohn, M.J., Spear, F.S., 1990. Two new geobarometers for garnet amphibolites, with applications to southeastern Vermont. Am. Miner. 75 (1-2), 89-96.

Konopásek, J., Caddick, M.J., 2016. Diffusional modification of prograde chemical zoning in garnet and its bearing on the estimates of prograde metamorphic conditions in medium to high grade rocks. In: EGU General Assembly Conference Abstracts, April, vol. 18 , p. 5533.

Lallemand, S., 2014. Strain modes within the forearc, arc and back-arc domains in the Izu (Japan) and Taiwan arc-continent collisional settings. J. Asian Earth Sci. 86, 1-11.

Lallemand, S., Heuret, A., Boutelier, D., 2005. On the relationships between slab dip, back-arc stress, upper plate absolute motion, and crustal nature in subduction zones. Geochem. Geophys. Geosyst. 6 (9).

Lallemand, S., Heuret, A., Faccenna, C., Funiciello, F., 2008. Subduction dynamics as revealed by trench migration. Tectonics 27 (3).

Larter, R.D., Vanneste, L.E., Morris, P., Smythe, D.K., 2003. Structure and tectonic evolution of the South Sandwich arc. Geol. Soc., Lond., Spec. Publ. 219 (1), 255-284.

Leake, B.E., Woolley, A.R., Birch, W.D., Burke, E.A., Ferraris, G., Grice, J.D., Hawthorne, F.C., Kisch, H.J., Krivochev, V.G., Schumacher, J.C., Stephenson, N., Whittaker, E.J., 2004. Nomenclature of amphiboles: additions and revisions to the International Mineralogical Association's amphibole nomenclature. Mineral. Magaz. 68 (1), 209-215.

Leat, P.T., Larter, R.D., 2003. Intra-oceanic subduction systems: introduction. Geol. Soc., Lond., Spec. Publ. 219 (1), 1-17.

Leblanc, M., 1981. The late Proterozoic ophiolites of Bou Azzer (Morocco): evidence for Pan-African plate tectonics. Develop. Precambr. Geol. 4, 435-451.

Leblanc, M., Billaud, P., 1978. A volcano-sedimentary copper deposit on a continental margin of upper Proterozoic age; Bleida (Anti-Atlas, Morocco). Econ. Geol. 73 (6), 1101-1111.

Leblanc, M., 1975. Ophiolites précambriennes et gites arséniés deCobalt (Bou Azzer, Maroc), $\mathrm{PhD}$ thesis. Centre géologique et géophysique de Montpellier, p. 329.

Lee, C.T.A., Anderson, D.L., 2015. Continental crust formation at arcs, the arclogite "delamination" cycle, and one origin for fertile melting anomalies in the mantle. Sci. Bull. 60 (13), 1141-1156.

Lee, Y., Cho, M., 2013. Fluid-present disequilibrium melting in Neoarchean arc-related migmatites of Daeijak Island, western Gyeonggi Massif, Korea. Lithos 179, 249-262.

Lee, C.T.A., Lackey, J.S., 2015. Global continental arc flare-ups and their relation to longterm greenhouse conditions. Elements 11 (2), 125-130.

López, S., Castro, A., 2001. Determination of the fluid-absent solidus and supersolidus phase relationships of MORB-derived amphibolites in the range 4-14 kbar. Am. Miner. 86 (11-12), 1396-1403.

Ludwig, K.R., 2003. Isoplot/Ex: Special Publication No. 4. Berkeley Geochronology Center, Berkeley, California.

Luvizotto, G.L., Zack, T., 2009. Nb and Zr behavior in rutile during high-grade metamorphism and retrogression: an example from the Ivrea-Verbano Zone. Chem. Geol. 261 (3), 303-317.

Macpherson, C.G., Dreher, S.T., Thirlwall, M.F., 2006. Adakites without slab melting: high pressure differentiation of island arc magma, Mindanao, the Philippines. Earth 
Planet. Sci. Lett. 243 (3), 581-593.

Martin, H., Smithies, R.H., Rapp, R., Moyen, J.F., Champion, D., 2005. An overview of adakite, tonalite-trondhjemite-granodiorite (TTG), and sanukitoid: relationships and some implications for crustal evolution. Lithos 79 (1), 1-24.

Martin, H., 1999. Adakitic magmas: modern analogues of Archaean granitoids. Lithos 46 (3), 411-429.

McDonough, W.F., Sun, S.S., 1995. The composition of the Earth. Chem. Geol. 120 (3-4), 223-253.

McLeod, C.L., Davidson, J.P., Nowell, G.M., de Silva, S.L., 2012. Disequilibrium melting during crustal anatexis and implications for modeling open magmatic systems. Geology 40 (5), 435-438.

Miller, D.J., Christensen, N.L., 1994. Seismic signature and geochemistry of an island arc: a multidisciplinary study of the Kohistan accreted terrane, northern Pakistan. J. Geophys. Res.: Solid Earth 99 (B6), 11623-11642.

Miyashiro, A., 1973. The Troodos ophiolitic complex was probably formed in an island arc. Earth Planet. Sci. Lett. 19 (2), 218-224.

Morris, P.A., 1995. Slab melting as an explanation of Quaternary volcanism and aseismicity in southwest Japan. Geology 23 (5), 395-398.

Moyen, J.F., Martin, H., 2012. Forty years of TTG research. Lithos 148, 312-336.

Mrini, Z., 1993. Chronologie (Rb-Sr, U-Pb), traçage isotopique (Sr-Nd-Pb) des sources des roches magmatiques éburnéennes, panafricaines et hercyniennes du Maroc, Unpubl thesis. Marrakech Univ, Morocco.

Müntener, O., Hermann, J., 2001. The role of lower crust and continental upper mantle during formation of non-volcanic passive margins: evidence from the Alps. Geol. Soc., Lond., Spec. Publ. 187 (1), 267-288.

Müntener, O., Ulmer, P., 2006. Experimentally derived high-pressure cumulates from hydrous arc magmas and consequences for the seismic velocity structure of lower arc crust. Geophys. Res. Lett. 33 (21).

Naidoo, D.D., Bloomer, S.H., Saquaque, A., Hefferan, K., 1991. Geochemistry and significance of metavolcanic rocks from the Bou Azzer-El Graara ophiolite (Morocco). Precambr. Res. 53 (1), 79-97.

Newton, R.C., Haselton, H.T., 1981. Thermodynamics of the garnet-plagioclase-Al2SiO5—quartz geobarometer. In: Thermodynamics of Minerals and Melts. Springer, New York, pp. 131-147.

Nikolaeva, K., Gerya, T.V., Connolly, J.A., 2008. Numerical modelling of crustal growth in intraoceanic volcanic arcs. Phys. Earth Planet. Inter. 171 (1), 336-356.

Orejana, D., Villaseca, C., Armstrong, R.A., Jeffries, T.E., 2011. Geochronology and trace element chemistry of zircon and garnet from granulite xenoliths: constraints on the tectonothermal evolution of the lower crust under central Spain. Lithos 124 (1), 103-116.

Otamendi, J.E., Tibaldi, A.M., Vujovich, G.I., Viñao, G.A., 2008. Metamorphic evolution of migmatites from the deep Famatinian arc crust exposed in Sierras Valle Fértil-La Huerta, San Juan, Argentina. J. S. Am. Earth Sci. 25 (3), 313-335.

Palin, R.M., White, R.W., Green, E.C., Diener, J.F., Powell, R., Holland, T.J., 2016. High-grade metamorphism and partial melting of basic and intermediate rocks. J. Metamorph. Geol. 34 (9), 871-892.

Paterson, S.R., Ducea, M.N., 2015. Arc magmatic tempos: gathering the evidence. Elements 11 (2), 91-98.

Pearce, J.A., Harris, N.B., Tindle, A.G., 1984. Trace element discrimination diagrams for the tectonic interpretation of granitic rocks. J. Petrol. 25 (4), 956-983.

Pin, C., Briot, D., Bassin, C., Poitrasson, F., 1994. Concomitant separation of strontium and samarium-neodymium for isotopic analysis in silicate samples, based on specific extraction chromatography. Anal. Chim. Acta 298 (2), 209-217.

Plissart, G., Diot, H., Monnier, C., Mărunţiu, M., Berger, J., 2012. Relationship between a syntectonic granitic intrusion and a shear zone in the Southern Carpathian-Balkan area (Almăj Mountains, Romania): implications for late Variscan kinematics and Cherbelezu granitoid emplacement. J. Struct. Geol. 39, 83-102.

Rahimi, A., Saidi, A., Baroudi, Z., Saquaque, A., Arboleya, M.L., 1998. Analyse pétrostructurale des mylonites de la zone de cisaillement de Bougmane (Bou Azzer-El Graara, Anti-Atlas Maroc). Annales-Société Géologique du Nord 6, 143-148.

Rapp, R.P., Watson, E.B., 1995. Dehydration melting of metabasalt at 8-32 kbar: implications for continental growth and crust-mantle recycling. J. Petrol. 36 (4), 891-931.

Ringuette, L., Martignole, J., Windley, B.F., 1999. Magmatic crystallization, isobaric cooling, and decompression of the garnet-bearing assemblages of the Jijal sequence (Kohistan terrane, western Himalayas). Geology 27 (2), 139-142.

Rioux, M., Mattinson, J., Hacker, B., Kelemen, P., Blusztajn, J., Hanghøj, K., Gehrels, G., 2010. Intermediate to felsic middle crust in the accreted Talkeetna arc, the Alaska Peninsula and Kodiak Island, Alaska: An analogue for low-velocity middle crust in modern arcs. Tectonics 29 (3)

Royden, L.H., Husson, L., 2009. Subduction with variations in slab buoyancy: models and application to the Banda and Apennine systems. Subduct. Zone Geodyn. 35-45.

Rubatto, D., 2002. Zircon trace element geochemistry: partitioning with garnet and the link between U-Pb ages and metamorphism. Chem. Geol. 184 (1), 123-138.

Rudnick, R.L., 1995. Making continental crust. Nature 378 (6557), 571-577.

Salters, V.J., Stracke, A., 2004. Composition of the depleted mantle. Geochem. Geophys. Geosyst. 5 (5).

Samson, S.D., Inglis, J.D., D'Lemos, R.S., Admou, H., Blichert-Toft, J., Hefferan, K., 2004. Geochronological, geochemical, and Nd-Hf isotopic constraints on the origin of Neoproterozoic plagiogranites in the Tasriwine ophiolite, Anti-Atlas orogen, Morocco. Precambr. Res. 135 (1), 133-147.

Saquaque, A., Benharref, M., Abia, H., Mrini, Z., Reuber, I., Karson, J.A., 1992. Evidence for a Panafrican volcanic arc and wrench fault tectonics in the Jbel Saghro, AntiAtlas, Morocco. Geologische Rundschau 81 (1), 1-13.

Saquaque, A., Admou, H., Karson, J., Hefferan, K., Reuber, I., 1989. Precambrian accretionary tectonics in the Bou Azzer-El Graara region, Anti-Atlas, Morocco. Geology 17
(12), 1107-1110

Sarbas, B., Nohl, U., 2008. The GEOROC database as part of a growing geoinformatics network. In: Brady, S.R., Sinha, A.K., Gundersen L.C. (Eds.), Geoinformatics 2008Data to Knowledge, U.S. Geol. Surv. Sci. Invest. Rep., 2008-5172, pp. 42-43.

Sawyer, E.W., 1991. Disequilibrium melting and the rate of melt-residuum separation during migmatization of mafic rocks from the Grenville Front, Quebec. J. Petrol. 32 (4), 701-738.

Sawyer, E.W., Brown, M. (Eds.), 2008. Working with Migmatites, vol. 38. Mineralogical Assn of Canada.

Schaltegger, U., Frank, M., Burg, J.P., 2003. A 120 million years record of magmatism and crustal melting in the Kohistan Batholith. In: EGS-AGU-EUG Joint Assembly, April, vol. 1 , p. 6816

Schärer, U., Labrousse, L., 2003. Dating the exhumation of UHP rocks and associated crustal melting in the Norwegian Caledonides. Contrib. Miner. Petrol. 144 (6), 758-770.

Shand, S.J., 1943. Eruptive Rocks: Their Genesis, Composition, and Classification, With a Chapter on Meteorites. J. Wiley and Sons, Incorporated.

Shaw, D.M., 1970. Trace element fractionation during anatexis. Geochim. Cosmochim. Acta 34 (2), 237-243.

Sizova, E., Gerya, T., Brown, M., Perchuk, L.L., 2010. Subduction styles in the Precambrian: insight from numerical experiments. Lithos 116 (3), 209-229.

Spear, F.S., Peacock, S.M., 1989. Petrologic determination of metamorphic pressuretemperature-time paths. In: Spear, F.S., Peacock, S.M. (Eds.), Metamorphic Pressure-Temperature-Time Paths, American Geophysical Union Short Corse in Geology, vol. 7, pp. 1-55.

Stacey, J.T., Kramers, 1., 1975. Approximation of terrestrial lead isotope evolution by a two-stage model. Earth Planet. Sci. Lett. 26 (2), 207-221.

Stern, R.J., Fouch, M.J., Klemperer, S.L., 2003. An overview of the Izu-Bonin-Mariana subduction factory. Inside Subduct. Fact. 175-222.

Stern, R.J., 2010. The anatomy and ontogeny of modern intra-oceanic arc systems. Geol. Soc., Lond., Spec. Publ. 338 (1), 7-34.

Stowell, H., Parker, K.O., Gatewood, M., Tulloch, A., Koenig, A., 2014. Temporal links between pluton emplacement, garnet granulite metamorphism, partial melting and extensional collapse in the lower crust of a Cretaceous magmatic arc, Fiordland, New Zealand. J. Metamorph. Geol. 32 (2), 151-175.

Sun, S.S., McDonough, W.S., 1989. Chemical and isotopic systematics of oceanic basalts: implications for mantle composition and processes. Geol. Soc., Lond., Spec. Publ. 42 (1), 313-345.

Takahashi, N., Kodaira, S., Tatsumi, Y., Yamashita, M., Sato, T., Kaiho, Y., Miura, S., No, T., Takizawa, K., Kaneda, Y., 2009. Structural variations of arc crusts and rifted margins in the southern Izu-Ogasawara arc-back arc system. Geochem. Geophys. Geosyst. 10 (9).

Takahashi, N., Kodaira, S., Klemperer, S.L., Tatsumi, Y., Kaneda, Y., Suyehiro, K., 2007. Crustal structure and evolution of the Mariana intra-oceanic island arc. Geology 35 (3), 203-206.

Tatsumi, Y., Shukuno, H., Tani, K., Takahashi, N., Kodaira, S., Kogiso, T., 2008. Structure and growth of the Izu-Bonin-Mariana arc crust: 2. Role of crust-mantle transformation and the transparent Moho in arc crust evolution. J. Geophys. Res.: Solid, Earth 113 (B2).

Taylor, R.J.M., Harley, S.L., Hinton, R.W., Elphick, S., Clark, C., Kelly, N.M., 2015. Experimental determination of REE partition coefficients between zircon, garnet and melt: a key to understanding high-T crustal processes. J. Metamorph. Geol. 33 (3), $231-248$.

Taylor, S.R., McLennan, S.M., 1985. The Continental Crust: Its Composition and Evolution. Blackwells Scientific, Oxford, pp. 312

Tetreault, J.L., Buiter, S.J.H., 2012. Geodynamic models of terrane accretion: testing the fate of island arcs, oceanic plateaus, and continental fragments in subduction zones. J. Geophys. Res.: Solid Earth 117 (B8).

Thomas, R.J., Chevallier, L.P., Gresse, P.G., Harmer, R.E., Eglington, B.M., Armstrong, R.A., de Beer, C.H., Martini, J.E.J., de Kock, G.S., Macey, P.H., Ingram, B.A., 2002. Precambrian evolution of the Sirwa window, Anti-Atlas orogen, Morocco. Precambr. Res. 118 (1), 1-57.

Thomas, R.J., Fekkak, A., Ennih, N., Errami, E., Loughlin, S.C., Gresse, P.G., Chevallier, L.P., Liégeois, J.P., 2004. A new lithostratigraphic framework for the Anti-Atlas Orogen, Morocco. J. Afr. Earth Sci. 39 (3), 217-226.

Tischendorf, G., Förster, H.J., Gottesmann, B., Rieder, M., 2007. True and brittle micas: composition and solid-solution series. Mineral. Mag. 71 (3), 285-320.

Tomkins, H.S., Powell, R., Ellis, D.J., 2007. The pressure dependence of the zirconium-inrutile thermometer. J. Metamorph. Geol. 25 (6), 703-713.

Toummite, A., Liégeois, J.P., Gasquet, D., Bruguier, O., Beraaouz, E.H., Ikenne, M., 2013. Field, geochemistry and Sr-Nd isotopes of the Pan-African granitoids from the Tifnoute Valley (Sirwa, Anti-Atlas, Morocco): a post-collisional event in a metacratonic setting. Mineral. Petrol. 107 (5), 739.

Triantafyllou, A., Berger, J., Baele, J.M., Diot, H., Ennih, N., Plissart, G., Monnier, C., Watlet, A., Bruguier, O., Spagna, P., Vandycke, S., 2016. The Tachakoucht-Iriri-Tourtit arc complex (Moroccan Anti-Atlas): neoproterozoic records of polyphased subduction-accretion dynamics during the Pan-African orogeny. J. Geodyn. 96, 81-103.

Uyeda, S., 1983. Comparative subductology. Episodes 2, 19-24.

Vogt, K., Gerya, T.V., 2014. From oceanic plateaus to allochthonous terranes: numerical modelling. Gondwana Res. 25 (2), 494-508.

Walsh, G.J., Benziane, F., Aleinikoff, J.N., Harrison, R.W., Yazidi, A., Burton, W.C., Quick, J.E., Saadane, A., 2012. Neoproterozoic tectonic evolution of the Jebel Saghro and Bou Azzer-El Graara inliers, eastern and central Anti-Atlas, Morocco. Precambr. Res. $216,23-62$.

Watson, E.B., Wark, D.A., Thomas, J.B., 2006. Crystallization thermometers for zircon 
and rutile. Contrib. Miner. Petrol. 151 (4), 413-433.

Watt, G.R., Burns, I.M., Graham, G.A., 1996. Chemical characteristics of migmatites: accessory phase distribution and evidence for fast melt segregation rates. Contrib. Miner. Petrol. 125 (1), 100-111.

Weisstein, E.W., 2002. CRC Concise Encyclopedia of Mathematics. CRC Press.

Whattam, S.A., Malpas, J., Ali, J.R., Smith, I.E., 2008. New SW Pacific tectonic model: cyclical intraoceanic magmatic arc construction and near-coeval emplacement along the Australia-Pacific margin in the Cenozoic. Geochem. Geophys. Geosyst. 9 (3).

White, R.W., Powell, R., Holland, T.J.B., Worley, B.A., 2000. The effect of TiO 2 an $\mathrm{Fe} \sim 2 \mathrm{O}-3$ on metapelitic assemblages at greenschist and amphibolite facies conditions: mineral equilibria calculations in the system $\mathrm{K} \sim 2 \mathrm{O}-\mathrm{FeO}-\mathrm{MgO}-\mathrm{Al} \sim 2 \mathrm{O} \sim 3$ $\mathrm{SiO} \sim 2-\mathrm{H} \sim 2 \mathrm{O}-\mathrm{TiO} \sim 2-\mathrm{Fe} \sim 2 \mathrm{O}-3$. J. Metamorph. Geol. 18 (5), 497-512.

White, R.W., Powell, R., Holland, T.J.B., Johnson, T.E., Green, E.C.R., 2014. New mineral activity-composition relations for thermodynamic calculations in metapelitic systems. J. Metamorph. Geol. 32 (3), 261-286.

Whitney, D.L., Evans, B.W., 2010. Abbreviations for names of rock-forming minerals. Am. Miner. 95 (1), 185.

Wiedenbeck, M.A.P.C., Alle, P., Corfu, F., Griffin, W.L., Meier, M., Oberli, F., Spiegel, W. 1995. Three natural zircon standards for U-Th-Pb, Lu-Hf, trace element and REE analyses. Geostand. Newslett. 19 (1), 1-23.

Wolf, M.B., Wyllie, P.J., 1994. Dehydration-melting of amphibolite at $10 \mathrm{kbar}$ : the effects of temperature and time. Contrib. Miner. Petrol. 115 (4), 369-383.

Yoshino, T., Okudaira, T., 2004. Crustal growth by magmatic accretion constrained by metamorphic P-T paths and thermal models of the Kohistan Arc, NW Himalayas. J. Petrol. 45 (11), 2287-2302.

Zack, T., Stockli, D.F., Luvizotto, G.L., Barth, M.G., Belousova, E., Wolfe, M.R., Hinton, R.W., 2011. In situ U-Pb rutile dating by LA-ICP-MS: 208Pb correction and prospects for geological applications. Contrib. Miner. Petrol. 162 (3), 515-530. 